\title{
A (IN)APLICABILIDADE DO CÓDIGO DE DEFESA DO CONSUMIDOR AOS CONTRATOS DE TRANSPORTE MARÍTIMO DE MERCADORIAS
}

\author{
Yago Jefferson Bezerra PEREIRA* e Brenda Camilli Alves FERNANDES \\ Instituto Federal de Educação, Ciência e Tecnologia do Rio Grande do Norte - IFRN \\ yago.jefferson@outlook.com*
}

DOI: 10.15628/observatorio.2014. 2897

\section{RESUMO}

Esse trabalho tem como foco o estudo da aplicação do Código de Defesa do Consumidor (CDC) aos contratos de transporte marítimo de mercadorias. Apresenta uma breve comparação entre os contratos marítimos e aéreos, os contratos de transporte marítimo de mercadorias, de pessoas e bagagens. A utilização do Código de Defesa do Consumidor para esses tipos de contratos, no modal aéreo, é unânime. $O$ trabalho tem como principal objetivo analisar a aplicabilidade do CDC aos contratos internacionais de transporte marítimo de mercadorias, bem como suas eventuais consequências. Dentro dos procedimentos metodológicos fez-se uso de pesquisa exploratória, centrada na aplicação do CDC aos contratos de transporte de mercadoria, por meio de levantamento de dados bibliográficos, bem como através da análise de jurisprudências colhidas no site do Superior Tribunal de Justiça (STJ). Os resultados mostram que a aplicabilidade do CDC em contratos de transporte marítimo de mercadorias apresenta resistências, porém observam-se brechas para a utilização de tal diploma legal. Percebe-se, uma tendência de aumento da aplicação do CDC num futuro breve, tornando-se mais uma ferramenta opcional para casos respectivos ao transporte marítimo, bem como, tendo uma importância significativa para as atividades do comércio exterior.

PALAVRAS-CHAVE: Contrato de transporte. Modal marítimo. Código de defesa do consumidor.

\section{THE (IN)APPLICABILITY OF CONSUMER PROTECTION CODE TO THE GOODS CONTRACTS OF CARRIAGE}

\begin{abstract}
This work focuses on the study of the application of the Consumer Protection Code (CDC) to maritime transport of Goods. Presents a brief comparison between maritime contracts and air, maritime transport contracts for goods, people and luggage. The use of the Consumer Protection Code for these types of contracts in air transport is unanimous. The work is meant to examine the applicability of the CDC contracts to international maritime transport of goods as well as their possible consequences. Within the methodological procedures was made use of exploratory research focused on the
\end{abstract}

application of the $\mathrm{CDC}$ to merchandise transport contracts, through survey of bibliographic data as well as through the analysis of jurisprudence harvested in the Superior Court of Justice's website (STJ). The results show that the applicability of the CDC in shipping of Goods offers resistance, but are observed loopholes for the use of such legislation. It is noticed a CDC application of an upward trend in the near future, becoming an optional tool for their cases to maritime transport, as well as having a significant importance to the activities of foreign trade.

KEYWORDS: Contract of Carriage. Shipping. Code of consumer protection. 


\section{INTRODUÇÃO}

Diante da evolução constante e acelerada das atividades comerciais, o uso do modal marítimo no transporte de mercadorias e/ou bagagens, pode ser considerado um instrumento de suma importância para as atividades do comércio exterior, assim como, para os procedimentos de transporte marítimo de mercadorias e/ou bagagens de uso próprio (pessoas físicas), sem a necessidade de a atividade ser realizada de forma contínua.

Segundo José Pedro Gonçalves, Chefe de Departamento de Operações do Conselho Nacional de Carregadores (CNC) da Angola em 2010, "A importância do transporte marítimo não precisa de facto de ser demonstrada, mas se se quiser recorrer a linguagem dos números verificase que mais de 80 por centos dos produtos objecto do comercio internacional são transportados por mar, percentagem essa que vai para mais de 90 por centos quando se trata de matériasprimas" (sic). Com isso, o presente trabalho tem como desafio analisar a aplicabilidade do Código de Defesa do Consumidor aos contratos de transporte de mercadorias.

O problema da pesquisa é identificar se a aplicação do Código de Defesa do Consumidor está pacificada nos tribunais e se é possível a sua utilização em contratos que regulem o transporte marítimo de mercadorias, em casos de má realização do transporte ou de prejuízos que possam advir deste contrato.

Diante do tema proposto, o trabalho tem como objetivo geral analisar a aplicabilidade do Código de Defesa do Consumidor nos contratos internacionais de transporte marítimo de mercadorias, bem como suas eventuais consequências. O estudo tentará responder o objetivo geral identificando os tipos de diplomas legais utilizados no transporte marítimo, o grau de importância dos mesmos quando se trata do contrato de transporte de mercadorias, através das opiniões de ministros e de análises de jurisprudências do Superior Tribunal de Justiça (STJ).

Para alcançar isto, a pesquisa tem como objetivos específicos facilitar a compreensão do contrato de transporte marítimo em suas diversas modalidades, e desenhar um panorama legal utilizado para reger os contratos de transporte marítimo e aéreo. Pretende-se ainda identificar a possibilidade de aplicação do Código de Defesa do Consumidor em contratos marítimos de transporte de passageiros e de mercadorias.

Atualmente o transporte marítimo vem sendo objeto de diversas discussões e questionamentos sobre as suas particularidades em comparação com as outras formas de transporte, tendo como foco o não englobamento do Código de Defesa do Consumidor nos contratos internacionais de transporte marítimo de mercadorias, diante do Código Comercial. Mas, é perceptível a possibilidade da utilização do CDC em alguns casos de operações comerciais. O Superior Tribunal de Justiça está discutindo a possibilidade da inclusão do CDC no transporte marítimo, apesar de ser uma questão polêmica, pois envolve de um lado exportadores e importadores, e do outro armadores e agentes de carga (NVOOC's).

A presente pesquisa tem como caráter metodológico ser uma pesquisa exploratória, por se tratar de um tema com pouca fundamentação teórica, assim como, apresentar opiniões divergentes, passando a ser um assunto cada vez mais presente nas discussões do Superior Tribunal de Justiça (STJ). Serão utilizados como procedimentos revisão bibliográfica, a livros, artigos e outras publicações disponíveis na internet para complemento da literatura e análise documental, a 
artigos de normas nacionais e internacionais e decisões exaradas por tribunais brasileiros, especialmente o Superior Tribunal de Justiça.

Por fim, o trabalho está estruturado em cinco capítulos que abordam respectivamente aspectos sobre contratos de transporte de forma geral, através de sua definição, classificação, interpretação e seus elementos gerais; assim como, os contratos de transporte marítimo com sua definição, leis aplicáveis aos seus contratos de compra e venda e seus tipos de contratos; a importância dos diversos tipos de transportes para o comércio exterior; os diplomas legais aplicados aos contratos de transporte; e, as análises jurisprudenciais com o intuito de subsidiar o estudo com aspectos empíricos, oriundos da observação do posicionamento do Poder Judiciário quanto à aplicação do CDC em contratos de transporte de mercadoria.

\section{METODOLOGIA}

De acordo com Lakatos e Marconi (2010, p. 269), a pesquisa qualitativa "[...] analisa e interpreta aspectos mais profundos." Por esta razão, faz-se a escolha pela pesquisa qualitativa para possibilitar o levantamento das informações sobre o tema em questão. O estudo tentará mostrar a importância do transporte marítimo no cenário do comércio exterior e suas aplicações, principalmente, no que diz respeito aos contratos de transporte de mercadorias, analisando as questões das leis que se aplicam aos contratos.

Ressalta-se também, para a presente pesquisa o método exploratório, que de acordo com os ensinamentos de Gil (2002, p. 41) "têm como objetivo proporcionar maior familiaridade com o problema, com vistas a torná-lo mais explícito". A pesquisa exploratória é recomendada quando há pouco conhecimento sobre o problema a ser estudado (CERVO; BERVIAN; DA SILVA, 2007, p. 61).

No procedimento para a coleta de dados, será utilizada a análise documental, especialmente as leis e jurisprudências, bem como, será disposto de revisão bibliográfica, a livros, artigos e outras publicações disponíveis na internet para complemento da literatura. Para a análise jurisprudencial utilizou-se como fonte principal o site do Superior Tribunal de Justiça, em razão de ser a corte suprema quanto à competência de matéria infraconstitucional.

A pesquisa tem como propósitos facilitar a compreensão do contrato de transporte e suas diversas modalidades, assim como, explicitar um panorama legal que rege os contratos de transporte marítimo, bem como, uma comparação com os contratos de transporte aéreo. Culminando, ainda, na análise da aplicação do Código de Defesa do Consumidor nos contratos marítimos de transporte de passageiros e mercadorias.

Por fim, ressalta-se que o caráter deste trabalho define-se como uma análise exploratória, visto que o trabalho apresenta questionamentos, por tratar-se de um tema com pouco conteúdo teórico, assim como, por se um assunto que está cada vez mais presente nas discussões do Superior Tribunal de Justiça (STJ), quando trata de contratos de transporte marítimo de mercadorias, analisando a aplicabilidade ou não do Código de Defesa do Consumidor. 


\section{CONTRATO DE TRANSPORTE}

Neste capítulo serão abordados os itens necessários para a elaboração de um contrato, assim como, a sua devida importância para que o acordo celebrado seja válido, tendo uma finalidade satisfatória para todas as partes. Será exposto nesse capítulo, respectivamente: a definição de contrato de transporte, as suas classificações, a interpretação do negócio jurídico e, os seus elementos gerais importantes.

\section{DEFINIÇÃO}

É de suma importância a definição do que vem a ser contrato de transporte, pois, através desse esclarecimento podem-se obter as noções básicas para estabelecer interesses que equilibrem as responsabilidades de ambas ou mais partes envolvidas no negócio jurídico.

Um contrato de transporte pode ser definido como, um negócio jurídico que envolve duas ou mais partes com uma finalidade em comum, onde uma tem como característica o pagamento e o recebimento da mercadoria/pessoa transportada e o outro o recebimento do valor da mercadoria e efetuar o transporte, no qual as mesmas possam apresentar seus interesses através das cláusulas definidas entre si, sejam estas orais ou escritas.

Segundo Diniz (2002, p. 369) a grande maioria dos autores aceita a teoria de Bullow, segundo a qual o negócio jurídico funda-se na "autonomia privada", ou seja, no poder de auto-regulação dos interesses que contém a enunciação de um preceito, independentemente do querer interno. Apresenta-se, então, o negócio jurídico como uma "norma concreta estabelecida pelas partes".

Maria Helena Diniz (2002, p. 369) faz questão em esclarecer a "autonomia privada", pois, essa autonomia não seria apenas a manifestação da vontade estabelecida no contrato, mas, também o efeito dessa manifestação associada à norma jurídica, de maneira que, cada parte envolvida possa se auto-regular.

Logo, para esta concepção não basta a mera manifestação da vontade para a aquisição de um direito, como, p. ex., a compra de uma casa; para a conversação de um direito, como exemplificativamente, um protesto judicial para resguardar futuro direito; para a transferência do direito, como a cessão de um compromisso de compra e venda; para a modificação de direito, como, p. ex., a novação de um contrato; e para a extinção do direito, como o caso da rescisão contratual. É necessário que tal efeito, visado pelo interessado, esteja conforme a norma jurídica; isto é assim porque a própria ordem jurídico-positiva permite a cada pessoa a prática de negócio jurídico, provocando seus efeitos. Este é o âmbito da "autonomia privada", de forma que os sujeitos de direito podem auto-regular, nos limites legais, seus interesses particulares (DINIZ, 2002, p. 369370).

Com a finalidade de esclarecer a definição de contrato, pode-se concluir de forma sucinta que, contrato vem a ser definido como "o poder de auto-regulação dos interesses que contém a enunciação de um preceito, independentemente do querer interno" (DINIZ, 2002, p. 370). 


\section{CLASSIFICAÇÃO DE CONTRATO}

Diante do que foi exposto sobre a definição de contrato de transporte, ressalta-se que, o negócio jurídico não é classificado apenas em um único aspecto geral, ou seja, o seguinte acordo é classificado em várias formas distintas. Sendo estas: a) quanto às vantagens que produzem, b) quanto às formalidades, c) quanto ao conteúdo, d) quanto à manifestação de vontade, e) quanto ao tempo em que produzem efeitos, f) quanto aos seus efeitos, g) quanto à sua existência $e, h$ ) quanto ao exercício dos direitos. A seguir, serão definidas as formas de classificação de contrato para melhor compreensão.

Têm-se quanto às vantagens que produzem, o contrato pode ser dividido em duas formas, em gratuitos e onerosos. No que se refere à primeira hipótese, pode-se afirmar que, será considerado gratuito, "se as partes obtiverem benefícios ou enriquecimento patrimonial sem qualquer contraprestação (p. ex.: doações)" (DINIZ, 2002, p. 370). E, os onerosos vêm a ser quando uma das partes envolvidas no contrato tem o objetivo de obter vantagens para si ou para terceiros.

Onerosos, se os sujeitos visarem, reciprocamente, a obter vantagens para si ou para outrem; assim, se suas prestações foram equivalentes e certas serão comutativos (p. ex.: compra e venda), se não o forem, aleatórios (p. ex.: contrato de seguro) (CC, arts. 757 a 802) (DINIZ, 2002, p. 370).

Em relação às formalidades, podem ser classificadas em solenes e não-solenes. A primeira é requerida em forma especial prescrita em lei, como por exemplo, em casos de testamento. $E, a$ segunda é solicitada quando não é necessária a sua exigência em forma legal para sua efetivação, por exemplo, compra e venda de móvel.

No que se refere ao conteúdo, pode-se dividir em patrimoniais e extrapatrimoniais. Os patrimoniais "se versarem sobre questões suscetíveis de aferição econômica, podendo apresentar-se ora como negócios reais, ora como negócios obrigacionais" (DINIZ, 2002, p. 370). E, os extrapatrimoniais "se atinentes aos direitos personalíssimos e ao direito de família" (DINIZ, 2002, p. 370).

Sobre a manifestação de vontade, pode-se afirmar que essa classificação diz respeito às vontades das partes envolvidas e, pode ser definida como unilateral e bilateral. A unilateral ocorre diante das vontades de um ou mais sujeitos, desde que provierem de um ato volitivo, porém, estando em busca de um único objetivo, como por exemplo, testamento, renúncia, promessa de recompensa (DINIZ, 2002, p. 370). A bilateral pode ser definida como a ocorrência diante da vontade de uma ou mais partes envolvidas, porém, com objetivos e sentidos contrários. Podendo ser simples ou sinalagmáticas.

Bilaterais, se a declaração volitiva emanar de duas ou mais pessoas, porém dirigidas em sentido contrário, podendo ser simples, quando concederem benefício a um das partes e encargo à outra (doação, depósito gratuito), e sinalagmáticos, quando conferirem vantagens e ônus a ambos os sujeitos (compra e venda, locação etc.) (DINIZ, 2002, p. 371).

Sobre o que se diz a respeito ao tempo em que produzem efeitos, classificam-se em inter vivos e mortis causa. Segundo Diniz (2002, p. 371) inter vivos, é definido quando acarreta-se 
consequências jurídicas na vida dos envolvidos, como por exemplo, adoção, troca, etc. e, a mortis causa é definida quando se regula as relações de direito após a morte do sujeito em questão, como nos casos de testamento ou legado.

E, o que se afirma quanto aos seus efeitos, estes são classificados em constitutivos e declarativos. Os constitutivos ocorrem quando a eficácia do contrato é de caráter ex nunc, ou seja, quando se têm o momento em questão encerrado, por exemplo, uma compra ou venda. Em relação aos declarativos, são aqueles no qual a eficácia do contrato tem caráter ex tunc, ou seja, só valerá quando o momento em que o fato ocorreu estiver vinculado à declaração da vontade, por exemplo, partilha ou divisão do condomínio (DINIZ, 2002, p. 371).

Já quanto à existência do negócio jurídico, pode ser classificada em principais e acessórias. As principais ocorrem se houver a existência por si só, independente de qualquer outro aspecto influenciador, por exemplo, locações. As acessórias ocorrem se a existência estiver sendo subordinada a um aspecto principal, por exemplo, uma fiança (DINIZ, 2002, p.371).

E, quanto ao exercício do direito, são classificadas em negócios de disposição e simples administração. Em relação a negócios de disposição é definido se implicar no exercício do direito sobre o objeto, como em casos de doação. E, simples administração "se concernentes ao exercício de direito restritos sobre o objeto, sem que haja alteração em sua substância (mútuo, locação de uma casa)" (DINIZ, 2002, p. 371).

\section{INTERPRETAÇÃO DO NEGÓCIO JURÍDICO}

Após definir as diversas classificações de contrato, é de suma importância demonstrar a interpretação dada ao negócio jurídico.

Segundo Diniz (2002, p. 372) “O negócio jurídico origina-se de ato volitivo, que colima a realização de um certo objetivo, criando, com base em normas jurídicas, direito subjetivo, e impondo, por outro lado, obrigações jurídicas".

A interpretação de contrato ocorre após a declaração da vontade das partes envolvidas, visto que, essa declaração pode gerar questões duvidosas entre os contratantes no que se refere às cláusulas contidas no mesmo.

"Essa declaração de vontade requer sempre uma interpretação, dado o fato da possibilidade de o negócio jurídico conter cláusula duvidosa, qualquer ponto obscuro ou controvertido" (DINIZ, 2002, p. 372).

Porém, a interpretação do negócio jurídico pode ocorrer através de três espécies: integrativa, declaratória ou construtiva. Segundo Diniz (2002, p. 372) a interpretação integrativa tem o intuito de preencher lacunas contidas no negócio jurídico. A declaratória tem o intuito de expressar a intensão dos interessados. E, a construtiva tem o objetivo de reconstruir o ato negocial, de forma que o mesmo não perca o seu valor. $E$, segundo os ensinamentos de Diniz (2002, p. 372) "Os negócios devem ser interpretados conforme a boa fé e os usos do lugar de sua celebração (CC, art. 113; RT, 375:226)".

No que se refere à doutrina e a jurisprudência, ambos tem entendido em matéria interpretativa que "em relação aos contratos deve-se ater à boa fé, às necessidades de crédito e à equidade (RT, 145:652; 180:663)” (DINIZ, 2002, p. 373). 


\section{ELEMENTOS GERAIS IMPORTANTES NA DEFINIÇÃO DE UM CONTRATO}

Neste subtópico serão analisados os elementos gerais essenciais para estabelecer um contrato, de forma que, o mesmo possa ser caracterizado como válido.

\subsubsection{Capacidade do agente}

A capacidade do agente surge quando ambas as partes envolvidas no negócio jurídico, tem capacidade de responder por si só pelos seus atos e por suas responsabilidades, ou, em alguns casos essa capacidade pode ser dada a terceiros, que segundo Monteiro (1966) apud Diniz (2002, p. 377) a interpretação ocorre através da relação jurídica, onde terceiros passam a se obrigar diretamente na relação em questão, através de ações em seu nome.

Segundo Diniz (2002, p. 377) "Se todo negócio jurídico pressupõe uma declaração da vontade, a capacidade do agente é indispensável à sua participação válida na seara jurídica (CC, art. 104, I)". Ressalta também que "os efeitos negociais advêm da declaração volitiva, que é sua causa efficiens" (DINIZ, 2002, p. 377).

O Código Civil (CC) em seus artigos $3^{\circ}$ e $4^{\circ}$ demonstra que um negócio jurídico válido não pode ser firmado com ou entre incapazes, ou seja, pessoas que ainda não respondem por seus próprios atos e responsabilidades. (CC, art. 120, 1a parte). Mas, o mesmo pode ser firmado, se o incapaz tiver como representante o seu responsável, estando em poder familiar. Como exemplo, pais, tutores e entre outros representantes, passando a responder pelos atos e as obrigações do incapaz.

Porém, "O ato praticado pelo absolutamente incapaz sem a devida representação é nulo (CC, art. 166, I) e o realizado pelo relativamente incapaz sem assistência é anulável (CC, art. 171, I)" (DINIZ, 2002, p. 377).

Segundo Diniz (2002, p. 377) vale observar ainda que a incapacidade relativa de uma das partes não pode ser invocada pela outra em benefício próprio, nem aproveita aos co-interessados capazes, salvo se, neste caso, for indivisível o objeto do direito ou da obrigação comum (CC, art. 105).

“Em questão de anulabilidade, a mesma só ocorrerá quando o ato praticado pelo representante consigo mesmo, forem em relação aos seus interesses ou contra outros. Exceto, se houver permissão legal" (DINIZ, 2002, p. 378).

\subsubsection{Objeto lícito e possível}

No que se refere ao objeto do contrato, o mesmo deve apresentar-se perante a lei com um caráter lícito. De maneira que, o mesmo possa ser anulado. Caso contrário, se o objeto for de caráter ilícito, o contrato será anulado.

Para que o negócio jurídico se repute perfeito e válido deverá versar sobre o objeto lícito, ou seja, conforme a lei, não sendo contrário aos bons costumes, à ordem pública e à moral. Se ilícito o seu objeto, nulo será o negócio jurídico (CC, art. 166, II), não produzindo qualquer efeito jurídico (RT, 395:165) (DINIZ, 2002, p.380). 
Sobre esse aspecto pode-se afirmar que, o objeto do contrato deve ser realizável e válido (CC, art. 426), pois, caso o mesmo não tenha condições necessárias de ser concretizado, o ato terá como sanção sua nulidade (CC, arts. 104 e 166). Por exemplo, uma viagem com a finalidade de dar uma volta no mundo no período de 6 horas. "Pelo art. 106 do Código Civil "a impossibilidade inicial do objeto não invalida o negócio jurídico se for relativa, ou se cessar antes de realizada a condição a que ele estiver subordinado"'” (DINIZ, 2002, p. 380).

\subsubsection{Consentimento}

Em relação ao consentimento estabelecido no negócio jurídico, pode-se afirmar que é o "ato ou efeito de consentir; licença; ordem; tolerância; aprovação; adesão" (AMORA, 1999, p. $165)$.

No ato negocial, o consentimento é dividido em duas espécies: Manifestação da vontade e defeitos do negócio jurídico. Espécies que serão analisadas a seguir.

\subsubsection{Manifestação da vontade}

A manifestação da vontade é um elemento de significativa importância e apresenta um papel relevante num negócio jurídico.

Maria Helena Diniz (2002, p. 380) reafirma os dizeres de R. Limongi França que define consentimento como "a ausência válida do sujeito a respeito do entabulamento de uma relação jurídica sobre determinado objeto".

Ainda referindo-se a manifestação da vontade, pode-se argumentar que, essa espécie é caracterizada em duas modalidades. Sendo estas, a modalidade expressa e a modalidade tácita. "Pode ser expresso ou tácito desde que o negócio, por sua natureza ou disposição legal, não exija forma expressa (CC, art. 432)" (DINIZ, 2002, p. 380).

A modalidade expressa será quando o contrato for declarado, de maneira escrita ou oral e ocorrer de modo explícito. Já a modalidade tácita, será definida quando num negócio jurídico ocorrer influência do comportamento do agente, demonstrando, implicitamente, sua ausência. Tendo também como fator influenciador, o silêncio do mesmo.

"Será expresso se declarado, por escrito ou oralmente, de modo explícito. Será tácito se resultar de um comportamento do agente, que demonstre, implicitamente, sua anuência" (DINIZ, 2002, p. 380).

Ou seja, a ideia de que quem cala consente, não apresenta valor jurídico na formação da manifestação da vontade num contrato em sua grande maioria, pois, o silêncio influência todo o processo do ato.

Logo a parêmia "quem cala consente" não tem juridicidade. Assim, quem ficar silente, o seu puro silêncio apenas terá valor jurídico se a lei o determinar, ou se acompanhado de certas circunstâncias ou de usos e costumes do lugar, indicativos da possibilidade de manifestação da vontade e desde que não seja necessária a forma expressa para a efetivação negocial (DINIZ, 2002, p. 381).

A grande maioria das manifestações da vontade tem caráter receptivo, pois, dirigem-se a uma determinada pessoa, a qual tem relação direta com o agente. 
A grande maioria das declarações de vontade, principalmente as da seara obrigacional, são receptícias por se dirigirem a uma determinada pessoa com o escopo de levar ao seu conhecimento a intenção do agente, ajustando-se a uma outra manifestação volitiva, para que surja o negócio jurídico. P. ex.: proposta do contrato (CC, arts. 427 e 428), revogação do mandato etc (DINIZ, 2002, p. 381).

Por outro lado, a manifestação deixa de apresentar caráter receptivo quando não se houver a necessidade de declarar a vontade da outra pessoa. Tendo caráter de não-receptível.

Serão não-receptícias se o negócio jurídico se efetivar com sua simples emissão pelo agente, sem que haja necessidade de qualquer declaração de vontade de outra pessoa. P. ex.: promessa de recompensa, aceitação de uma letra de câmbio, testamento, legado etc (DINIZ, 2002, p. 381).

\subsubsection{Defeitos do negócio jurídico}

No que se diz respeito aos defeitos do negócio jurídico, nota-se que em sua grande parte, ocorrem quando o negócio jurídico deixa de ter valor negocial, para apenas apresentar um valor de aparência, ou seja, sem que a manifestação da vontade tenha, de fato, ocorrido.

"Tanto isso é verdade que se a vontade for inexistente o negócio jurídico existe apenas de fato na aparência, mas não no mundo jurídico, pois será nulo." (DINIZ, 2002, p. 381).

Diniz (2002, p. 381-382) afirma também que caso à abertura de anulação do contrato ocorra por vício ou outro fator, o negócio jurídico tornara-se anulável num prazo decadencial de quatro anos (CC, arts. 178, I e II e 171, I; RT, 390:371; 397:318).

Diante da anulação do contrato, pressupõe-se que associado a essa anulação surge a hipótese da ligação entre a vontade interna e sua manifestação, de maneira que, aconteça um desvio da lei, da boa fé, assim, infringindo o direito e prejudicando terceiros envolvidos. Isto faz com que, o negócio jurídico passe a ter caráter de invalidação.

Existem, ainda, hipóteses em que se tem uma vontade funcionando normalmente, havendo até correspondência entre a vontade interna e sua manifestação, entretanto, ela desvia-se da lei, ou da boa fé, infringindo o direito e prejudicando terceiros, sendo, por isso, o negócio jurídico, que assim se apresentar, suscetível de invalidação. Trata-se dos vícios sociais, como a simulação que o tornará nulo (CC, art. 167, caput) e a fraude contra credores que o tornará anulável (CC, art. 171, II, in fine; 178, II), que comprometem a ordem jurídica pela afronta à lisura, à honestidade e à regularidade do comércio jurídico (DINIZ, 2002, p. 382).

Sendo assim, têm-se definidos como vícios de consentimento: o erro, o dolo, a coação, o estado de perigo e a lesão. Vícios que estão fundamentados no desiquilíbrio da atuação volitiva em sua declaração.

Desta forma, analisaremos cada tipo de vício de consentimento a seguir:

Uma possibilidade de vício de contrato é o erro, que seria uma manifestação não sincera, não realista, diante de um ato jurídico ou um aspecto formal ou oral definido no momento de firmação de um contrato. 
Num sentido geral erro é uma noção inexata, não verdadeira, sobre alguma coisa, objeto ou pessoa, que influencia a formação da vontade. Se influi na vontade do declarante, impede que se forme em consonância com sua verdadeira motivação; tendo sobre o fato ou sobre um preceito noção incompleta, o agente emite sua vontade de modo diverso do que a manifestaria se dele tivesse conhecimento exato ou completo (DINIZ, 2002, p. 382-383).

Outra definição de erro por Fubini (1902) é "o estado da mente, que por defeito do conhecimento do verdadeiro estado das coisas, impede uma real manifestação da vontade" (DINIZ, 2002, p. 383).

No que se observa pelo Código Civil, pode-se dizer que, os aspectos e o assunto em torno do vício pelo erro estão regulados pelos arts. 138 a 144 do CC (Diniz, 2002, p. 383).

No pressuposto de anulação referente ao erro, o contrato só será anulável quando o erro for identificado e o pedido de anulação for solicitado. Vale lembrar ainda, que o erro é requisito de anulação como caráter secundário, assim como, substancial.

"Um das partes não pode beneficiar-se com o erro de outra. Deve ser real, palpável e reconhecível pela outra parte, importando efetivo prejuízo para o interessado" (DINIZ, 2002, p. 383).

Outra característica do erro é ser definido como erro escusável, ou seja, seria o erro justificável, justificando todas as circunstâncias envolvidas no ato, na celebração do contrato.

Arnoldo Wald pontifica que o conceito de escusabilidade deve ser elástico, competindo ao juiz, em cada caso concreto, analisar o nível cultural do agente, como o alcance de sua inteligência, suas qualidades profissionais, dentre outras circunstâncias (RT, 119:829; 90:438; 116:268; 138:126; 241:138; 181:307; RF, 101:321) (DINIZ, 2002, p. 384).

Ressalta-se também que diante desse vício, basta apenas que uma das partes identifique e compartilhe o erro ocorrido para que o negócio jurídico venha a ser anulável.

No Código Civil Brasileiro de 1916, não se tinha a possibilidade de anulação de contrato por vício de erro. Segundo Clóvis Beviláqua as noções do erro do direito, assim como, a ignorância da lei eram equiparadas e opinadas pela inexistência do error juris ante o art. 3으 da Lei de Introdução ao Código Civil (DINIZ, 2002, p. 385).

A Lei de Introdução ao Código Civil, atualmente conhecida como Lei de Introdução às normas do Direito Brasileiro no art. $3^{\circ}$, relata que

"Ninguém se escusa de cumprir a lei, alegando que não a conhece. Portanto, o erro de direito não era considerado como causa de anulação do contrato. Só o erro de fato podia influir, de modo a anulá-lo, sobre a eficácia do elemento volitivo" (DINIZ, 2002, p. 385).

De qualquer maneira, para anular o negócio é necessário que esse erro tenha sido o motivo único e principal a determinar a vontade, não podendo, contudo, recair sobre a norma cogente, mas tão-somente sobre normas dispositivas, sujeitas ao livre acordo das partes. Tal entendimento veio a ser coroado com o disposto no novo Código Civil, no art. 139, III (DINIZ, 2002, p. 386). 
No vício por erro, tem-se o erro acidental, o erro in quantitate, o erro de cálculo e o erro quanto ao fim colimado (falso motivo).

O erro acidental seria o erro ocorrido às circunstâncias secundárias e acessórias da pessoa, ou do objeto, não induzindo a anulação do negócio por não incidir sobre a declaração da vontade (Diniz, 2002, p. 386).

O erro in quantitate, afirmado por Diniz $(2002$, p. 386) seria o erro que diz respeito ao engano sobre peso, medida ou quantidade de um bem.

O erro de cálculo tem a função de autorizar a retificação da declaração volitiva (CC, art. 143), porém, não vindo a anular o ato.

E, o erro quanto ao fim colimado (falso motivo) segundo Diniz (2002, p. 387) é o erro que não vicia, em sua regra, ao negócio jurídico, a não ser quando ocorre o vício quando a nele se figurar de maneira expressa, sendo assim, sua razão essencial ou determinante, fazendo com que venha a se tornar anulável.

"É o que preceitua o Código Civil no art. 140, que assim prescreve: "O falso motivo só vicia a declaração de vontade, quando expresso como razão determinante"”' (DINIZ, 2002, p. 387).

Outro fator importante a se destacar no vício por erro é que a responsabilidade da anulação do negócio jurídico será da parte que pediu a anulação do contrato. Sendo essa responsabilidade denominada de interesse negativo.

Quanto ao Dolo, tem-se que é o ato de gerar prejuízo a uma das partes, beneficiando o autor do dolo e prejudicando a parte que sofreu a ação. Dessa forma, o ato negocial é regido por questões maliciosas, em razão das quais, o prejudicado passa a sofrer as maiores consequências por indução, tendo um prejuízo patrimonial.

\footnotetext{
Segundo Clóvis Beviláqua, é o emprego de um artifício ou expediente astucioso para induzir alguém à prática de um ato que o prejudica e aproveita ao autor do dolo ou a terceiro. Essa manobra astuciosa (macchinatio) pode sugerir o falso ou suprimir o verídico, mediante mentiras (allegatio falsi) ou omissões (DINIZ, 2002, p.389).
}

Por outro lado, Carvalho Santos e Larenz apud Diniz (2002, p. 389) não concordam com a definição proposta por Clóvis Beviláqua. Ambos acreditam que, o fator principal da ocorrência do dolo não é o prejuízo decorrente da ação do autor do dolo para com a outra parte. E sim, quando a parte que sofre o dolo é atraída a efetuar o contrato.

Entretanto, Diniz (2002, p. 389) afirma que, a razão está na definição de Beviláqua, que apesar de acontecer à ocorrência do dolo havendo um prejuízo patrimonial, esse prejuízo está em conformidade com a vantagem do autor do dolo, ocorrendo à efetivação do contrato com manobras de caráter malicioso afetando a manifestação da vontade.

O erro deriva de um equívoco da própria vítima, sem que a outra parte tenha concorrido para isso, ao passo que o dolo é, intencionalmente, provocado na vítima pelo autor do dolo ou por terceiro, sendo, portanto, passível de anulação (CC, arts. 145, 171, II, 178, II; RT, 444:112) (DINIZ, 2002, p. 389). 
Assim como o erro, o dolo apresenta diversas formas, sendo as seguintes: Dolus bonus ou malus, Dolus causam ou principal e Dolus incidens ou acidental, e Dolo positivo ou negativo.

Dolus bonus ou malus: O Dolus bonus seria o dolo que não tem como finalidade prejudicar alguém, tendo um comportamento lícito e tolerável. Esse tipo de dolo não induz a anulabilidade (DINIZ, 2002, p. 389). Já o Dolus malus seria o oposto do bonus, pois tem como finalidade prejudicar alguém com manobras astuciosas. Este dolo é tratado em nosso Código Civil, de maneira a apresentar sua anulabilidade.

"Não há normas absolutas que possibilitem diferenciar essas duas espécies de dolo, cabendo ao órgão judicante, em cada caso concreto, levar em conta a inexperiência e o nível de informação da vítima" (DINIZ, 2002, p. 390).

Dolus causam ou principal ou Dolus incidens ou acidental: O Dolus causam é praticado durante o processo de execução do negócio jurídico, de maneira que, o mesmo possa ser anulado antes mesmo de ser concluído.

"O dolo principal é aquele que dá causa ao negócio jurídico, sem o qual ele não se teria concluído (CC, art. 145), acarretando, então, a anulabilidade daquele negócio" (DINIZ, 2002, p. 390).

Para que o dolo principal se configure, segundo Espínola, é preciso que: a) haja intenção de induzir o declarante a praticar o negócio jurídico, desde que, no entender de Clóvis e Serpa Lopes, ocorra prejuízo para vítima; b) os artifícios fraudulentos sejam graves, aproveitando a quem os alega; c) sejam causa determinante da declaração da vontade; e d) procedam do outro contratante, ou sejam deste conhecidos, se procedentes de terceiros (DINIZ, 2002, p. 390).

E, o Dolus incidens é o dolo que leva a alguém realizar o negócio jurídico de maneira menos satisfatória, de forma que, esse indivíduo terá maiores prejuízos. Esse tipo de dolo não gera anulabilidade, apenas perdas ou redução da prestação acordada no contrato firmado de maneira onerosa.

O dolo acidental é o que leva a vítima a realizar o negócio, porém em condições mais onerosas ou menos vantajosas (CC, art. 146), não afetando sua declaração da vontade, embora provoque desvios, não se constituindo vício de consentimento, por não influir diretamente na realização do ato, que se teria praticado independentemente do emprego de artifícios astuciosos (DINIZ, 2002, p. 390).

O dolo positivo ocorre por uma ação dolosa onde alguém é levado a realizar o negócio jurídico através de informações falsas em relação a um objeto em questão.

O dolo positivo ou comissivo é o artifício astucioso que consta de ação dolosa, ou seja, é o dolo por comissão em que a parte é levada a contratar, por força de artifícios positivos, ou seja, informações falsas sobre a qualidade da coisa. P.ex.: captação de testamento; cotação falsa da Bolsa de Valores para induzir alguém a adquirir ações (DINIZ, 2002, p. 391).

Por fim, o dolo negativo ocorre por uma ação dolosa a alguém que deveria ter sabido ou sabe da ocorrência desse dolo, de maneira a não levá-lo a concluir o negócio. 
O dolo negativo ou omissivo (CC, art. 147) é a manobra astuciosa que constitui uma omissão dolosa ou reticente; dá-se quando uma das partes oculta alguma coisa que o co-contratante deveria saber e se sabedor não teria realizado o negócio (RT, 545:198) (...) P. ex.: (...) se alguém quer vender um imóvel e não encontra comprador que the pague o preço pretendido por estar o terreno sujeito a desapropriação pela Municipalidade, oculta, então, que o imóvel é objeto de declaração de utilidade pública e consegue vendê-lo, é também hipótese de dolo por omissão (DINIZ, 2002, p. 391-392).

Entende-se que a coação seria o ato de obrigar, ameaçar alguém a realizar um contrato de forma a beneficiar o autor da ameaça. Seria qualquer pressão física ou até mesmo moral que possa obrigar ou induzir um contratante a efetivar um negócio jurídico. Pode, portanto, ser classificado em coação física (vis absoluta) ou moral (vis compulsiva)

A coação física (vis absoluta) tem como fator principal a ação corporal, ou seja, acarreta na ocorrência de um constrangimento corpóreo em alguém, de maneira que, possa esse tipo de coação tornar nula sua manifestação de vontade, pois o indivíduo foi levado de maneira forçada a realizar o contrato, havendo o consentimento de vontade.

\begin{abstract}
A física ou vis absoluta é o constrangimento corporal que retira toda a capacidade de querer, implicando ausência total de consentimento, o que acarreta nulidade do ato, não se tratando de vício da vontade. P..ex.: se alguém segura a mão da vítima, apontando-lhe uma arma, para obter a assinatura de um documento (DINIZ, 2002, p. 395).
\end{abstract}

A coação moral (vis compulsiva) assim como a física, tem como um fator o constrangimento da parte de quem sofre a coação, porém, na vis compulsiva o indivíduo que sofre a ação tem a possibilidade de escolha.

A moral ou vis compulsiva atua sobre a vontade da vítima, sem aniquilar-lhe o consentimento, pois conserva ela uma relativa liberdade (RT, 80:87), podendo optar entre a realização do negócio que lhe é exigido e o dano com que é ameaçada. P. ex.: o assaltante que ameaça a vítima dizendo: "a bolsa ou a vida"; esta tem uma alternativa, ou entrega a bolsa ou sofre as consequências da ameaça - perda da vida. A coação moral é modalidade de vício de consentimento, pois permite que o coacto emita uma vontade, embora maculada, acarretando a anulabilidade (CC, art. 171, II e 178, I) do negócio por ele realizado (DINIZ, 2002, p. 395).

Segundo Diniz (2002, p. 396) para que possa ocorrer à coação moral são necessários alguns requisitos (CC, art. 151), tais como o dano deve ser considerável ou grave, a coação deve ser a causa determinante do negócio jurídico, o temor incutido à vítima deve ser fundado ou iminente, entre outros (DINIZ, 2008, p. 396-397).

Não haverá coação, tendo por base o previsto no Código Civil, quando ocorrer uma ameaça do exercício normal de um direito, nem quando acontece um simples temor reverencial.

Segundo Diniz (2002, p. 397) na primeira hipótese deve-se ocorrer uma ação injusta, de forma que, se ocorrer uma ação de caráter justo, irá acarretar num direito do ameaçador e não do ameaçado. 
P. ex.: se um credor de dívida vencida e não paga ameaçar o devedor de protestar o título e requerer a falência, não se configura a coação por ameaça justa que se prende ao exercício normal de um direito, logo o devedor que não pode reclamar a anulação do protesto (RT, 296:310) (DINIZ, 2002, p. 397).

Na segunda hipótese, Diniz (2002, p. 398) expõe a ideia de Clóvis Beviláqua que relata sobre a questão do desrespeito aos pais, familiares e entre outros a quem se deveria respeitar, de forma que, tornará o negócio jurídico vicioso e de natureza incapaz.

Simples temor reverencial (RT, 479:258), que é, segundo Clóvis, o receio de desgostar pai, mãe ou pessoas a quem se deve obediência e respeito, é incapaz de viciar o negócio, desde que não seja acompanhado de ameaças ou violências irresistíveis (RT, 60:339; 274:333; 182:950) (DINIZ, 2002, p. 398).

Por último, encontramos o vício caracterizado como lesão e estado de perigo, que acontece quando um terceiro ligado à parte fraca envolvida no contrato celebrado se dispõe a assumir os riscos, livrando o personagem anterior dos danos.

"O instituto da lesão visa proteger o contratante, que se encontra em posição de inferioridade, ante o prejuízo por ele sofrido na conclusão do contrato, devido à desproporção existente entre as prestações das duas partes" (DINIZ, 2002, p. 398).

Essa forma de consentimento apresenta duas hipóteses, a primeira é a lesão usurária e a segunda é a lesão especial.

A lesão usurária é a lesão que tem como característica tirar vantagem, de induzir alguém a realizar o negócio jurídico para que se possa obter vantagem da mesma (DINIZ, 2002, p. 399). Pode-se afirmar também que, apenas esse tipo de lesão se configurava no antigo direito brasileiro.

Tal lesão está contida apenas na Lei n. 1.521/51, que, no seu art. 4ํㅡ, $b$, assim estatui: "Obter ou estipular qualquer contrato, abusando da premente necessidade, inexperiência ou leviandade de outra parte, lucro patrimonial que exceda o quinto do valor corrente ou justo da prestação feita ou prometida", portanto vem a considerá-la como crime contra a economia popular e no Código de Defesa do Consumidor, art. 39, ao tratar das práticas abusivas do fornecedor de bens ou serviços (DINIZ, 2002, p. 399).

A lesão especial é a lesão que ocorre quando surge um exagero nas vantagens e desvantagens estabelecidas no negócio jurídico entre as partes envolvidas, seja por inexperiência ou por questões individuais, porém, não acarretando em má fé e proveito de vantagem de uma das partes.

Trata-se de lesão especial ou qualificada, terminologia proposta por Antônio Junqueira de Azevedo, por se limitar à exigência de excesso nas vantagens e desvantagens, causada pela necessidade ou inexperiência de uma das partes, ao efetivar o contrato sem cogitar de dolo de aproveitamento da parte beneficiada, ou seja, não há que se indagar da má fé ou ilicitude da conduta do outro concorrente (DINIZ, 2002, p. 399). 
Segundo Diniz (2002, p. 399) a lesão especial terá como sua sanção a anulabilidade, prescrita nos arts. 171, II e 178, II, tendo como objetivo eliminar os aspectos desproporcionais para que o negócio jurídico possa ser capaz de aproveitamento (art. 157, § 2ㅇ).

Para maior esclarecimento pode-se dizer que, a lesão é caracterizada como um dano sofrido por uma das partes envolvidas no contrato, na maioria dos casos, essa parte é a mais frágil, sem experiência e noção sobre o assunto (DINIZ, 2002, p. 399).

Por fim, Diniz (2002, p. 401) conclui que estado de perigo é quando ocorre uma ação de dano moral grave onde o indivíduo é forçado a concluir o contrato.

No estado de perigo haverá temor de grave dano moral ou material à pessoa que compele o declarante a concluir o contrato, mediante prestação exorbitante. Pelo art. 156 do Código Civil ter-se-á estado de perigo quando alguém, premido pela necessidade de salvar-se, ou pessoa de sua família, de grave dano conhecido pela outra parte, assume obrigação excessivamente onerosa. E, em se tratando de pessoa não pertencente à família do declarante, o juiz decidirá pela ocorrência, ou não, do estado de perigo, segundo as circunstâncias (CC, art. 156, parágrafo único) e seu bom senso (LICC, art. 5ㅇ). A pessoa em estado de perigo assume comportamento que não teria conscientemente (DINIZ, 2002, p. 401).

\section{CONTRATO DE TRANSPORTE PROPRIAMENTE DITO}

O contrato de transporte tem como função determinar uma relação onde, o autor por realizar o transporte, assume a responsabilidade de entregar a mercadoria sã e salva, sem nenhum problema, para a parte contratante no negócio jurídico. Dessa forma, quando o consignatário recebe a mercadoria em bom estado, afirma-se que, o objetivo do contrato foi realizado.

Conforme aduz o vigente Código, contrato de transporte é aquele que "uma pessoa ou empresa se obriga, mediante retribuição, a transportar, de um local para outro, pessoas ou coisas animada ou inanimada" (CC, art. 730).

Por outro lado, Diniz (2007, p. 467) ressalta que o Código Civil de 1916, não apresentava nenhuma ideia sobre contrato de transporte em seu texto. Nesse período, as formalidades referentes ao contrato de transporte e a utilização do meio de transporte (ônibus, caminhões e entre outros) ainda estavam em fase inicial no Código Civil Brasileiro.

O contrato de transporte, apesar de ser um dos negócios jurídicos mais usuais, não foi regulamentado pelo Código Civil de 1916, e muito escassamente disciplinava o Código Comercial, referindo-se apenas nos arts. 99 a 118 aos condutores de gêneros e comissários de transporte (DINIZ, 2007, p. 467).

Segundo Miyada (2010), Clóvis Beviláqua, por volta da década de 1980, elaborou um projeto que tratava das questões do transporte coletivo (meio que iniciou o processo de elaboração da regulamentação do contrato de transporte no Brasil). Com isso, houve-se a necessidade de formular uma lei com o objetivo de regulamentar o transporte coletivo e, posteriormente com a evolução do Código Civil Brasileiro, os outros meios de transporte. 
É importante afirmar que, a definição do contrato de transporte engloba todas as modalidades de meio de condução (terrestre, marítimo, aéreo ou ferroviário) utilizadas para a prestação de serviço.

Em relação à espécie, o contrato de transporte pode ser caracterizado como de coisas ou pessoas. Como exemplo, empresas de transporte de turismo são responsáveis por transportar pessoas de um lugar a outro e, indiretamente, também são responsáveis pela segurança das coisas dos passageiros. Por outro lado, as bagagens não são consideradas coisa, conforme pode ser observado abaixo.

\begin{abstract}
Pode ser de pessoas ou de coisas, esse conceito é unânime e não diverge de nenhum doutrinador. Fica de total responsabilidade do transportador a integridade física do passageiro, dando todo o aconchego e espaço prometido no contrato, camarote, poltrona, aperitivos, hidratação, etc. Assim como deve também preservar a integridade e a guarda da coisa transportada. Uma observação importante é que a bagagem do passageiro não caracteriza coisa nesse caso, ele é equiparado ao bem acessório do contrato, não obstante a diversidade dos princípios aplicáveis. (Miyada, 2010).
\end{abstract}

Conforme Miyada (2010), no que se trata dos sujeitos envolvidos no contrato de transporte, têm-se o remetente ou carregador, o comissário de transporte e o destinatário ou consignatário. O remente é o responsável que envia a mercadoria, ou seja, é o expedidor que envia o produto ao transportador. O comissário de transporte é o responsável por intermediar o transporte, necessitando de um transportador. E, o destinatário ou consignatário é o que recebe a mercadoria.

Por fim, o contrato de transporte tem como função esclarecer o papel das partes envolvidas no negócio jurídico, assim como, suas responsabilidades e deveres, com o objetivo de transportar mercadorias ou pessoas de um lugar a outro sem ocorrência de danos.

\title{
4 CONTRATO DE TRANSPORTE MARÍTIMO
}

Nesse capítulo será abordada a definição de contrato de transporte, especialmente o marítimo, os tipos de contratos de transporte marítimo e a responsabilidade que pode advir diante dos diferentes tipos de negócio jurídico.

\section{DEFINIÇÃO}

Nesse momento cabe a definição do que seria contrato de transporte marítimo internacional de mercadoria, que segundo Octaviano (2008, p. 73) entende-se que é um contrato internacional onde as partes envolvidas no mesmo tenham suas residências habituais ou estejam sediadas em Estados-partes diferentes.

Entende-se que um contrato é internacional quando as partes no mesmo tiverem sua residência habitual ou estabelecimento sediado em diferentes Estados-partes ou quando o contrato tiver vinculação objetiva com mais de um Estado-parte (OCTAVIANO, 2008, p. 73). 
Vale salientar que aspectos logísticos, operacionais e jurídicos são definidos como fatores pré-contratuais que influenciam as etapas no estabelecimento de um contrato, em quaisquer tipos de contratos firmados como o de próprio transporte, de fretamento e de seguro.

Outro ponto importante a se mencionar é que o contrato de transporte marítimo de caráter internacional apresenta as mesmas características básicas de qualquer outro tipo de contrato, sendo um acordo firmado entre um comprador (importador) e um vendedor (exportador), existindo obrigações recíprocas, assim como, as responsabilidades e os pagamentos necessários das taxas para a liberação da mercadoria e o recebimento pelo comprador.

Os contratos marítimos se formam na sequência de um contrato internacional de compra e venda que define, entre outros aspectos, as responsabilidades do exportador (vendedor) e do comprador no tangente a contratação e pagamentos de frete e seguro, e assunção de riscos durante a expedição marítima (OCTAVIANO, 2008, p. 74).

\section{LEIS APLICÁVEIS AO CONTRATO DE TRANSPORTE DE COMPRA E VENDA}

Sobre as leis aplicáveis ao contrato de transporte marítimo internacional, pode-se afirma, segundo Octaviano (2008, p. 99) que o contrato de transporte de compra e venda é formulado tendo como base o convênio da Organização das Nações Unidas (ONU) sobre os Contratos de Compra e Venda Internacional de Mercadorias de 1980 ou observando regras internacionais sobre práticas comerciais.

Ainda sobre as leis utilizadas nessa modalidade de contrato, pode-se observar a aplicação do princípio da autonomia da vontade no direito brasileiro e a legislação aplicável de escolha do foro em sede de direito brasileiro ou do local de celebração a esse tipo de contrato; assim como, a Convenção de Viena de 1980; a Convenção Interamericana de Direito Internacional Privado, e a autonomia da vontade nos estados-membros do MERCOSUL.

O princípio da autonomia da vontade no direito brasileiro, assim como, a sua legislação aplicável esclarece que diante da formalização do contrato a nossa legislação faz uso do critério da celebração com conformidade com o art. 9o da Lei de Introdução ao Código Civil (LICC), ou seja, a lei de autonomia da vontade está ligada ao local de celebração do contrato onde as partes se fazem presentes, ou, quando não presentes, o local de residência da parte que apresenta a proposta. É importante ressaltar também que atualmente, a Lei de Introdução ao Código Civil é nomeada como Lei de Introdução às normas do Direito Brasileiro.

No tangente às obrigações quanto a sua substância e efeitos, a legislação brasileira restringe o princípio da autonomia da vontade; adota o critério de sua celebração (lex loci contractus) em conformidade com o art. 9o da Lei de Introdução ao Código Civil. Efetivamente, em consonância ao comando normativo supra citado, a lei aplicável aos contratos será, nos contratos entre presentes (caput), a do local de celebração do contrato, e, nos entre ausentes, a de onde residir o proponente $\left(\$ 2^{\circ}\right)$ (OCTAVIANO, 2008, p. 100).

Já a Convenção de Viena de 1980 é utilizada apenas entre países signatários da convenção e que tenham interesse de realizar contratos de compra e venda de mercadoria entre si, mas que estejam em estados distintos, utilizando também as normas de direito internacional privado, em 
especial o artigo primeiro. A Convenção apenas tem a função de firmar o contrato entre as partes, assim como, os direitos e obrigações das partes.

A Convenção de Viena consagra a autonomia da vontade e permite que as partes excluam de seu contrato a incidência total ou parcial de suas disposições, derroguem quaisquer de suas disposições ou alterem seus efeitos (art. $6^{\circ}$ ) (OCTAVIANO, 2008, p. 101).

A interpretação da Convenção tem como princípio o seu artigo sétimo que relata a necessidade de promover a uniformidade; um caráter internacional e a necessidade de assegurar a observância da boa fé no comércio internacional. Por outro lado, a Convenção não julga necessária a formalização de um contrato escrito, podendo ser realizado oralmente.

"O contrato de compra e venda não necessita de instrumento escrito, nem está sujeito a qualquer requisito de forma. O contrato pode ser provado por qualquer meio de prova admissível em direito" (OCTAVIANO, 2008, p. 101).

Em relação às obrigações, a Convenção de 1980 deixa claro o papel do comprador que é de pagar o preço da mercadoria e recebê-la em boas condições (arts. 53 e 54) e, do vendedor de entregar a mercadoria, enviar os documentos cabíveis e informar quando não for sua obrigação, a necessidade do comprador contratar um seguro (art. 30, 32 e 32, 3).

Um aspecto importante na Convenção de Viena de 1980 é a realização de transferência de risco entre as partes, que acontece através de utilização de termos denominados de INCOTERMS ${ }^{1}$, dessa maneira, deixará de usar as regras da convenção.

Fonseca (2002) apud Octaviano (2008, p. 103) afirma que se presume o comprador encontrar-se em posição mais favorável para inspecionar as mercadorias que tiverem sido deterioradas enquanto foram transportadas, bem como para requerer indenização por perdas e danos do transportador ou da companhia seguradora: "A responsabilidade do vendedor termina quando o primeiro transportador toma posse dos bens. É indispensável, assim, que o transportador seja uma terceira pessoa, que não se confunde com os sujeitos contratuais".

Fonseca apud Octaviano (2008, p. 103) também afirma que o uso dos INCOTERMS não deixa de lado a adoção de soluções elaboradas pela própria Convenção. De maneira que, o texto da Convenção e os INCOTERMS se completam.

Sobre os importadores e exportadores brasileiros, a Convenção de Viena não os comprometia, pois, o Brasil na época não era signatário da Convenção de 1980.

A Convenção de Viena não afeta exportadores e importadores brasileiros em casos de contratos entre presentes firmados no Brasil quando for aplicável a lei brasileira (v. art. $9^{\circ}$, caput, da LICC; válido para contratos entre presentes; lei aplicável é a do local de celebração do contrato) (OCTAVIANO, 2008, p. 106).

\footnotetext{
1 Os INCOTERMS s ão regras internacionais para interpretação de fórmulas contratuais típicas criadas pela International Chamber of Commerce - ICC, em 1936, e revisadas em 1953, 1967, 1976, 1980, 1990, 2000 e, o mais recente em 2010.
} 
A Convenção Interamericana de Direito Internacional Privado, também permite o uso da autonomia da vontade, assim como, a escolha da lei aplicável pelas partes na formulação do contrato. Vale salientar que, o Brasil é signatário da Convenção Interamericana de Direito Internacional Privado (Cidip V) de 1994, porém ainda não a incorporou no ordenamento jurídico (OCTAVIANO, 2008, p. 99).

Assim como a Convenção de Viena de 1980, a Convenção Interamericana de Direito Privado também é realizada apenas entre países signatários. Em caso de uso das regras, a Cidip V dá a possibilidade do uso do Direito Brasileiro dentro da Convenção entre os signatários e o uso da Lei de Introdução do Código Civil (LICC), hoje conhecida como Lei de Introdução às normas do Direito Brasileiro, como também da Convenção de Viena de 1980.

Encontram-se em trâmite o PL n.4.095/95, que substituiria a LICC e adota princípio da autonomia, e o PL n.269/2004, que também consagra a autonomia da vontade e é reedição do PL n.4.905/94. Ressalta-se, ainda, o PL n.243/2002, que intenta alterar as regras do DIP, mas não consagra a autonomia da vontade propondo, porém, alterações significativas (OCTAVIANO, 2008, 106).

A autonomia da vontade nos estados-membros do MERCOSUL esclarece que todos os países-membros do bloco são signatários da Convenção Interamericana, porém, nem todos a ratificaram. Um exemplo de ratificação é a Argentina, que é signatária da Convenção de Viena e a ratificou (OCTAVIANO, 2008, p.107).

Rechsteiner (2003, p. 139) apud Octaviano (2008, p. 107) afirma que além da aceitação da autonomia da vontade ter um impacto mundial, "a autonomia da vontade das partes não é reconhecida ainda como elemento de conexão, juridicamente válido, que possa reger relações de direito privado com conexão internacional, em grande parte da América Latina".

\title{
TIPOS DE CONTRATO DE TRANSPORTE MARÍTIMO
}

Em relação aos tipos de contratos de transporte marítimo, é de importância esclarecer que é a negociação ${ }^{2}$ estabelecida na esfera internacional e é formalizada por meio de um contrato de compra e venda de mercadoria também de caráter internacional (OCTAVIANO, 2008, p. 92).

\begin{abstract}
Diante dos ensinamentos de Moreira (2007), o contrato de transporte marítimo internacional pode ser considerado um dos mais antigos do mundo, pois desde os primórdios as civilizações utilizam o transporte sobre as águas para comercializar riquezas e exercer atividades comerciais.
\end{abstract}

O contrato de transporte pode ser definido como "aquele em que uma pessoa ou empresa se obriga, mediante retribuição, a transportar, de um local para outro, pessoas ou coisas animadas ou inamimadas" (CC, art. 730). (sic)

Diante dos aspectos pré-contratuais (logísticos, operacionais e jurídicos) num contrato internacional, é importante também analisar os custos e a segurança jurídica da mercadoria a ser

\footnotetext{
${ }^{2}$ Negociação é um processo em que duas ou mais partes, com interesses comuns ou antagônicos, se reúnem para confrontar e discutir propostas explícitas com o objetivo de alcançar um acordo (Berlew apud Carvalhal, 2011).
} 
transportada, diante do contexto estabelecido entre os Estados-partes. A segurança jurídica no contrato é firmada quando é imposta uma maior segurança no momento da negociação, da elaboração e das assinaturas no contrato escrito pelas partes envolvidas de forma clara, sucinta e objetiva.

\begin{abstract}
A melhor estratégia de delegar maior segurança jurídica e maior previsibilidade à relação contratual consiste em negociação, elaboração e assinatura de um contrato escrito detalhado pelas próprias partes contendo definição precisa, objetiva e inequívoca de todos os elementos fundamentais intrínsecos àquela relação específica (OCTAVIANO, 2008, p. 95).
\end{abstract}

Vale ressaltar que o contrato de transporte marítimo é definido pelo conhecimento de embarque ou conhecimento de carga, em inglês denominado como Bill of Lading - BL (MOREIRA, 2007).

Sobre as cláusulas importantes que um contrato de transporte marítimo internacional de compra e venda de mercadoria deve conter, Octaviano (2008, p. 96-98) mostra-as da seguinte maneira: i) Cláusulas introdutórias: identificação de partes contratantes; tipo de contrato ou motivação da formalização; ii) Cláusulas específicas: a) Objeto do contrato: descrição e código da mercadoria; b) Preço e condições de venda: a cláusula deve fixar, inclusive por extenso, o preço unitário e total do produto a ser comercializado. Deve, ademais, indicar a moeda específica do preço indicado para efeitos cambiários; c) Lei aplicável; d) Obrigações do vendedor: data e lugar de entrega das mercadorias e de faturas, certificados e documentos de transporte; e) Obrigações do comprador: pagamento, recebimento das mercadorias; f) Transferências de riscos, responsabilidades quanto a contratação e pagamento de seguro e transporte, custos e propriedade. É desejável utilização dos Incoterms. Na hipótese de não-utilização de Incoterms, as cláusulas deverão ser detalhadas e específicas; g) Modalidade de pagamento: carta de crédito, cobrança ou pagamento antecipado; h) Prazo de: fabricação, entrega, pagamento, embarque; i) Documentação exigida: conhecimento de embarque (bill of lading - BL marítimo, ou airway bill aéreo); fatura comercial (commercial invoice); romaneio de embarque (packing list); apólice ou certificado de seguro (insurance policy or certificate); certificado de peso (weight certificate); certificado de qualidade (quality certificate); certificado de inspeção (inspetion/test certificate); fatura consular (consular invoice) entre outros; j) Permissão ou não para embarques parciais ou transbordo; k) Exigências de transporte especial; I) Penalizações; m) Idiomas; n) Cláusulas de garantia: visam a minimizar riscos de desconformidade de mercadoria. Comumente, tais cláusulas estabelecem períodos de garantias e, no caso de diferença entre o produto e entregue e o solicitado no contrato, o exportador se compromete a trocar o produto, substituindo peças defeituosas ou desconformes, ou, alternativamente, fornecer quantidade adicional do produto para completar o volume total de peças não respeitado no embarque da mercadoria e etc; o) Força maior (force majeure): cláusula de exoneração de responsabilidade das partes contratantes em circunstâncias nas quais o cumprimento de uma determinada obrigação contratual torna-se impossível; o evento ocorre fora do controle das partes contratantes, ou seja, as partes não contribuírem de forma alguma com a realização do evento; o evento ser imprevisível; ou, ainda, o caso de as partes tentarem impedir sua ocorrência, mas sem sucesso.

Outras cláusulas específicas competentes na formulação do contrato marítimo são, a duração que é fixa um marco temporal a partir do qual o contrato produzirá seus efeitos jurídicos 
e define um período de vigência para a relação contratual; a Cláusula hardship (hardship clause): assegura o direito das partes de poder solicitar reajuste do contrato, na ocorrência de alteração dos termos econômicos-financeiros que vigoraram e propiciaram a base inicial do contrato, para reaver o equilíbrio inicial vigente no momento da formação do acordo; a escolha do foro ou cláusula compromissória arbitral: a redação da cláusula compromissória, para ser considerada eficaz, deverá comtemplar os seguintes elementos essenciais: corte permanente ou de arbitragem onde será realizado o procedimento arbitral; cidade onde será realizada a arbitragem; número de árbitros; regras que serão utilizadas pelos árbitros; e o idioma no qual será conduzido a arbitragem.

Dessa forma, podemos observar que para que um contrato de transporte marítimo internacional de compra e venda venha a ser firmado, o processo de elaboração é criterioso, dando uma maior segurança para as partes envolvidas, reafirmando a questão de segurança jurídica.

\subsubsection{Contrato de transporte marítimo de pessoas e bagagens}

O contrato de transporte de pessoas e bagagens como o próprio nome esclarece é realizado pela relação entre o transportador e o consumidor, que tem como objetivo transportar mercadorias e/ou bens de uma ou mais pessoas, assim como, o próprio indivíduo de um lugar para o outro.

Diante do artigo 2ㅇ do Código de Defesa do Consumidor, define-se como consumidor "toda e qualquer pessoa física ou jurídica que adquire ou utiliza produto ou serviço como destinatário final".

Essa modalidade de contrato é em grande parte formalizada entre uma pessoa jurídica e uma pessoa física (consumidora final), de forma que, o produto ou bem de posse da pessoa física deixe de fazer parte da cadeia produtiva, não gerando lucro.

Octaviano em seu artigo intitulado "A incidência do Código de Defesa do Consumidor nos contratos marítimos de transporte de mercadorias" publicado no portal âmbito jurídico em janeiro de 2010 afirma que, diante dos entendimentos jurídicos e doutrinários, é considerável a utilização do Código de Defesa do Consumidor nos contratos de transporte marítimo, ressaltando que se deve fazer a diferenciação dos tipos de negócio jurídico, assim como, sendo fundamental a identificação de relação de consumo para que se aplique o referido diploma legal.

Com isso, Octaviano (2008, p. 356) afirma que "no transporte de passageiros, é praticamente unânime o entendimento que propugna pelo influxo do referido Código no contrato de transporte".

\subsubsection{Contrato de transporte marítimo de mercadorias}

Assim como o contrato de transporte marítimo de passageiros, o contrato de transporte marítimo de mercadoria também deixa claro a que objetivo ele se propõe.

O contrato de transporte de mercadorias pode ser realizado entre pessoas jurídicas ou entre pessoa jurídica e pessoa física, sendo mais comum ocorrer a primeira situação. Quando o contrato ocorre com pessoa física, é importante mencionar que a mercadoria mesmo em sua 
posse poderá ou não de certa forma ainda continuar fazendo parte da cadeia produtiva, ou seja, gerando lucro.

Octaviano (2008, p. 356) esclarece que de forma contrária ao contrato de pessoas e bagagens, o contrato de transporte de mercadorias não recebe a influência do Código de Defesa do Consumidor.

"Todavia, a mesma unanimidade já não se detecta no concernente aos contratos de transporte marítimo de mercadorias" (OCTAVIANO, 2008, p. 356).

Por outro lado, as pessoas jurídicas podem ser consideradas como destinatárias finais se as mesmas utilizarem o serviço de transporte, passando a serem classificadas como consumidores.

Porém, Octaviano (2008, p. 357) evidencia que apesar das pessoas jurídicas poderem ser classificadas como consumidores, caso ocorra o uso de serviço de transporte, ainda existem divergências jurisprudenciais e doutrinárias sobre essa questão. De forma que, para diferenciar a relação de consumo no contrato de transporte de mercadorias, utilizam-se duas teorias, a teoria finalista e maximalista.

A teoria finalista afirma que para que ocorra a relação de consumo, o destinatário final deve ser caracterizado como aquele que não irá reutilizar a mercadoria fornecida na cadeia produtiva, mesmo que de forma indireta. Sendo a teoria finalista adotava pela maioria das nossas jurisprudências.

Diante dos ensinamentos de Octaviano (2008, p. 358), o consumidor é classificado em destinatário final fático e econômico. Onde o fático, tem como função retirar o produto da cadeia de produção e o econômico, fazer com que a mercadoria não seja utilizada para revenda ou uso profissional.

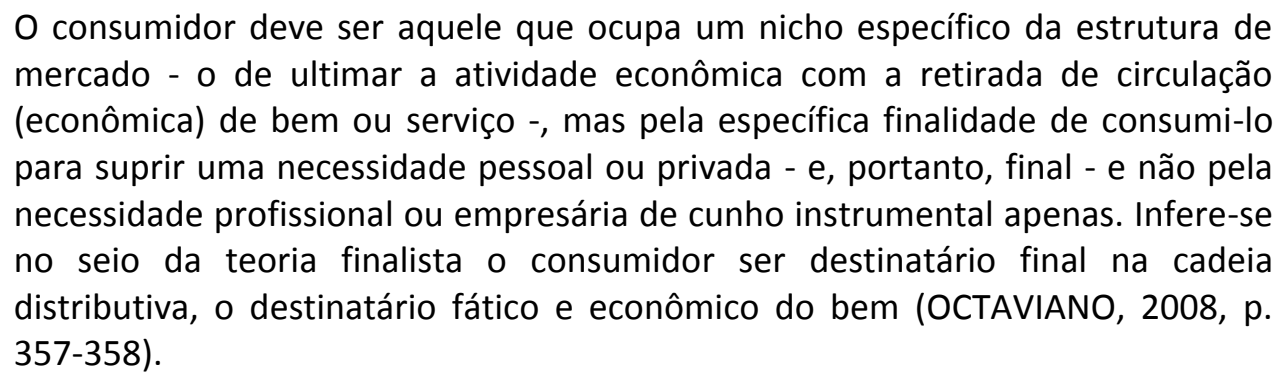

Já a teoria maximalista, apresenta uma visão mais ampla e, ao contrário da teoria finalista, define consumidor como toda pessoa física ou jurídica, seja de caráter profissional ou não.

"A teoria maximalista desponta mais ampla e visa a abranger a maior gama de relações contratuais possíveis, enquadrando, de forma irrestrita, toda pessoa física ou jurídica como merecedora de proteção, seja ela profissional ou não" (OCTAVIANO, 2008, p. 359).

Segundo os ensinamentos de Octaviano (2008, p. 359), a corrente maximalista não enquadra a vulnerabilidade como pressuposto básico e necessário à caracterização do sujeito como um consumidor. 
Segundo Octaviano (2008, p. 360) na teoria maximalista não importa para a definição de destinatário final, seja ele fático ou econômico, o que é feito com o produto transportado. O que importa para essa teoria é apenas a realização do transporte, desde que tenha sido realizado de maneira satisfatória.

Para os maximalistas, não importa para a definição do destinatário final do serviço de transporte o que é feito com o produto transportado. No caso, o serviço de transporte foi consumado com a chegada da mercadoria em seu destino, terminando aí a relação de consumo estabelecida entre a transportadora e empresa que a contratou. Nesse diapasão, insere-se, essencialmente, a atividade de transporte (OCTAVIANO, 2008, p. 360).

\section{RESPONSABILIDADES DIANTE DOS TIPOS DE CONTRATOS}

A responsabilidade civil no ordenamento jurídico brasileiro é a obrigação de se reparar um prejuízo em virtude de algum dano ocorrido (GUTIÉRREZ; CASTRO, 2013).

Diante dos ensinamentos de Gutiérrez e Castro (2013), a responsabilidade civil está prevista no art. 927 do Código Civil (CC), que informa:

Art. 927. Aquele que, por ato ilícito (arts. 186 e 187), causar dano a outrem, fica obrigado a repará-lo.

Parágrafo único. Haverá obrigação de reparar o dano, independentemente de culpa, nos casos especificados em lei, ou quando a atividade normalmente desenvolvida pelo autor do dano implicar, por sua natureza, risco para os direitos de outrem.

É notável que diante dos pressupostos, o que define o dever de indenizar é o dano, ou seja, o fato. O momento e a situação que ocorre a causa que gerará o ato de indenização pelo agente.

O dano pode ser caracterizado como moral ou patrimonial, dependendo da situação ocorrida. O dano moral (pessoal ou extrapatrimonial) ocorre devido às questões de valor pessoal do indivíduo diante dos bens envolvidos no ato (OCTAVIANO, 2008, p. 526). Já os danos patrimoniais (materiais) ocorrem na propriedade da vítima em questão, ou seja, dos seus bens materiais pessoais e econômicos.

O dano patrimonial (material) atinge frontalmente o patrimônio da vítima, ou seja, incide sobre o interesse material ou econômico, refletindo-se no patrimônio lesado e reduzindo de forma determinável a valoração, que deve ser indenizada para que se reconduza o patrimônio ao seu status quo ante, seja para uma reposição in natura, seja por equivalente pecuniário (OCTAVIANO, 2008, p. 526). 
Octaviano (2008, p. 526) ainda afirma que "no ordenamento jurídico brasileiro, os danos morais e materiais estão amparados pelo art. $5^{\circ}, X$, da Constituição Federal de 1988, bem como nos arts. $186^{3}, 187^{4}$, e de $927^{5}$ a $943^{6}$ do Código Civil".

A limitação da responsabilidade no direito marítimo internacional é de grande importância para as atividades marítimas e no estabelecimento contratual, que segundo Gutiérrez e Castro (2013) são regulados por diversas convenções internacionais. E, no que se refere ao transporte de passageiros, pode-se afirmar que é regulado por convênios internacionais importantes.

Por outro lado, o Brasil na ótica de responsabilidade civil, na modalidade de transporte de mercadorias, faz parte de um acordo firmado em 1924 que atualmente está obsoleto e, nos contratos de passageiros, o Brasil não faz parte de nenhum acordo ou convenção, fazendo com que as causalidades passem a ser resolvidas através do Código Civil (GUTIÉRREZ e CASTRO, 2013).

Já Cremoneze apud Gutiérrez e Castro (2013) afirma que, na modalidade de transporte por via marítima de passageiros, a responsabilidade civil é baseada na teoria objetiva imprópria, que diz que a culpa do fato será presumida com foco no transportador.

No que se diz respeito à responsabilidade civil e a teoria objetiva, pode-se afirmar que, a responsabilidade civil é definida diante do acordo contratual em si, que visa proteger as partes envolvidas e, a teoria objetiva tem como característica o fato de que certas atividades têm por si só um fator de risco, fazendo com que tenha a capacidade de indenização.

A responsabilidade civil contratual visa proteger o princípio da norma pacta sunt servanda, pois significa que os acordos devem ser cumpridos fielmente, segundo o que foi pactuado entre as partes. Já a teoria objetiva se baseia no fato de certas atividades profissionais em si só um risco, fazendo assim com que o responsável por esta atividade tenha o dever de indenizar (GUTIÉRREZ e CASTRO, 2013).

Em relação ao contrato de transporte de passageiros, Júnior apud Gutiérrez e Castro (2013) esclarece que diante do pacto contratual não é o passageiro que tem como função mostrar a responsabilidade do transportador, mas o próprio transportador.

Osvaldo Agripino de castro Júnior, esclarece que não é o passageiro ou dono da mercadoria quem deve provar a culpa do transportador, mas sim o transportador, pois esse é quem deve provar da sua responsabilidade por meio da ausência de culpa (GUTIÉRREZ e CASTRO, 2013).

Outro ponto importante diante da responsabilidade contratual é definir o que seria responsabilidade civil contratual e extracontratual, que segundo Octaviano $(2008$, p. 527) a responsabilidade civil contratual de forma geral está centralizada no inadimplemento contratual e a responsabilidade civil extracontratual ou aquilina está centralizada no ilícito extracontratual.

\footnotetext{
${ }^{3}$ Art. 186. Aquele que, por ação ou omissão voluntária, negligência ou imprudência, violar direito e causar dano a outrem, ainda que exclusivamente moral, comete ato ilícito.

${ }^{4}$ Art. 187. Também comete ato ilícito o titular de um direito que, ao exercê-lo, excede manifestamente os limites impostos pelo seu fim econômico ou social, pela boa-fé ou pelos bons costumes.

${ }^{5}$ Art. 927. Aquele que, por ato ilícito (arts. 186 e 187), causar dano a outrem, fica obrigado a repará-lo.

${ }^{6}$ Art. 943. O direito de exigir reparação e a obrigação de prestá-la transmitem-se com a herança.
} 
Independente da forma de responsabilidade contratual, Octaviano (2008, p. 527-528) esclarece os elementos necessários para o estabelecimento dessas responsabilidades como sendo: i) fato lesivo voluntário, ou imputável, causado pelo agente por ação ou omissão voluntaria (dolo), negligencia imprudência, ou imperícia (culpa), incorrendo em violação do direito subjetivo individual; ii) ocorrência de dano patrimonial ou moral; iii) nexo de causalidade entre o dano e a conduta ilícita do agente.

No caso do transporte de mercadorias, as questões de responsabilidades contratuais giram em torno de avarias, perdas e atrasos que ocorrem devidos o descumprimento das obrigações contratuais nos contratos.

Por outro lado, conforme Gutiérrez e Castro (2013) o transportador pode demonstrar ausência de responsabilidade civil em determinados casos, como: ausência de nexo casual; culpa exclusiva da vítima; caso fortuito e força maior. Porém, os mesmos autores afirmam que quando ocorrer responsabilidade por culpa concorrente, ou seja, de ambos os lados, será firmada culpa de ambos e uma responsabilidade menor, pode ser dividida entre os responsáveis.

Ademais, quando a responsabilidade ocorrer em decorrência da culpa concorrente, será estabelecida uma média de culpa de cada parte e assim será reduzida a responsabilidade (GUTIÉRREZ; CASTRO, 2013).

Um aspecto importante na responsabilidade contratual é a Súmula $187^{7}$ do Supremo Tribunal Federal (STF) que unificou o pensamento dos juristas que afirmam que serão responsáveis os transportadores por acidentes com passageiros, mesmo que ocorra ato de culpa, sendo cabível uma ação entre o transportador e um terceiro causador do dano (GUTIÉRREZ; CASTRO, 2013).

Quando se trata do Código de Defesa do Consumidor, pode-se afirmar que este dispositivo é utilizado no contrato de transporte de passageiros de forma natural. Pois, de acordo com Gutiérrez e Castro (2013) esse tipo de contrato de transporte não apresenta uma legislação específica acerca do tema, de maneira que, a legislação brasileira não apresenta um regime voltado para esse tipo de contrato e sim apenas legislações voltadas para o campo macroeconômico do direito marítimo, especificadamente.

Por outro lado, Gutiérrez e Castro (2013) esclarecem que apesar de não existir uma legislação específica para essa forma de contrato, existem diversas convenções e acordos internacionais que servem de apoio, porém o Brasil não os ratificou. Entre elas, a Convenção de Atenas de 2002, que segundo os autores busca estabelecer a responsabilidade do transportador por danos aos passageiros e, em alguns casos, até mesmo faz com que ele não seja responsabilizado, porém, esses convênios estabelecem limites para a responsabilidade do transportador.

Convenção de Atenas 2002, buscam estabelecer a responsabilidade do transportador por danos aos passageiros e, em alguns casos, até mesmo faz com que ele não seja responsabilizado. Por outro lado, estes convênios incluem limites à responsabilidade do transportador (GUTIÉRREZ; CASTRO, 2013). (sic)

\footnotetext{
7 Súmula 187: A responsabilidade contratual do transportador, pelo acidente com o passageiro, não é elidida por culpa de terceiro, contra o qual tem ação regressiva.
} 


\section{A IMPORTÂNCIA DOS TRANSPORTES PARA O COMÉRCIO EXTERIOR}

Nesse capítulo serão abordados os meios de transporte disponíveis no cenário internacional, tais como: transporte marítimo, aéreo, ferroviário e rodoviário, assim como, a importância de cada modalidade de transporte no comércio exterior brasileiro com maior ênfase no transporte marítimo.

\section{OS MEIOS DE TRANSPORTE UTILIZADOS NO COMÉRCIO INTERNACIONAL}

Quando se trata de venda e/ou compra de mercadoria, é notório que para realizar o envio e/ou recebimento de mercadorias entre os países, têm-se a necessidade de utilizar uma modalidade de transporte durante esse processo, que são definidas de acordo com o caminho que será percorrido. Tais modalidades que serão discutidas a seguir.

\subsubsection{Transporte marítimo}

De acordo com o portal "aprendendo a exportar" da Secretaria de Comércio Exterior Brasileiro (SECEX), na seção planejamento a exportação e subseção planejamento estratégico, o transporte marítimo é considerado a modalidade de transporte mais utilizada no cenário brasileiro, com cerca de $90 \%$ de utilização e um dos fatores que gera essa porcentagem é o baixo custo do transporte.

\footnotetext{
O transporte marítimo representa, praticamente, a totalidade dos serviços de transporte no comércio exterior. Sua grande utilização no transporte internacional, atualmente responsável por cerca de $90 \%$ das cargas, é dado devido ao seu baixo custo (Aprendendo a exportar, disponível em: http://www.aprendendoaexportar.gov.br/maquinas/planejando_exp/plan_estra tegico/logistica/trans_m.asp).
}

Segundo Nunes (2007) o transporte marítimo é uma modalidade que se limita a movimentação de cargas de um porto a outro nas mais diversas regiões do mundo, usando diferentes tipos de navios, sendo também considerado um transporte utilizado nas cadeias de multimodais otimizando o transporte global. O autor afirma que o uso desse transporte dar-se pela necessidade do comércio de mercadorias de um país ao outro, sendo organizado por tipos de cargas, volumes de carga, distribuição de cargas, tempo de trajeto e outros.

No ano de 2007, o Ministério de Desenvolvimento, Indústria e Comércio Exterior (MDIC) apud Nascimento (2007) informou que o transporte marítimo passou a ser considerado no respectivo ano o transporte mais utilizado no cenário internacional, assim como, seu papel de elo entre os modais terrestres e marítimos, observando que ainda no mesmo ano as exportações brasileiras por modais ocorreram da seguinte forma, respectivamente: marítima; fluvial; aérea; postal; ferroviária; rodoviária e; meios próprios.

José Pedro Gonçalves, chefe de Departamento de Operações do Conselho Nacional de Carregadores (CNC) da Angola em 2010, afirmou que os fatores que levaram ao sucesso do transporte marítimo foram a sua vantagem competitiva e a sua capacidade de deslocar diversas mercadorias em grande quantidade por longas distâncias por um baixo custo. Porém, Gonçalves 
mostra que a desvantagem dessa modalidade é a velocidade, que comparada com os outros tipos de transportes, é inferior.

\begin{abstract}
A importância do transporte marítimo não precisa de facto ser demonstrada, mas se quiser recorrer a linguagem dos números verifica-se que mais de 80 por cento dos produtos objecto do comercio internacional são transportados por mar, percentagem essa que vai para mais de 90 por centos quando se trata de matérias-primas (GONÇALVES, 2010). (sic)
\end{abstract}

Já a Agência Nacional de Transporte Aquaviários (ANTAQ) em 2001, afirmou que a via marítima é a principal modalidade de uso para o transporte de mercadorias do comércio exterior brasileiro. Tendo em 2011 em tonelagem exportada o valor em porcentagem de 96\% do total e em relação às importações de $89 \%$. Mostrando ainda que, analisando o fluxo comercial com referência no valor (US\$ FOB), pode-se observar que a participação desse transporte vem crescendo nos últimos anos, de forma que detém $84 \%$ do montante exportado e $76 \%$ do importado, sendo caracterizado como o melhor patamar desde 2007.

Um dado importante, revelado por Nunes apud Araújo; Cleto; Jung; Dutra; Paulo; Gabriel (2013) é que "existem atualmente cerca de 30 mil navios realizando o transporte de quase seis milhões de toneladas anuais no comércio internacional. $O$ tráfego marítimo mundial é dividido, por tipo de carga, em graneis líquido, com participação de $36 \%$ da tonelagem total transportada, graneis sólidos, com $36,5 \%$ e carga geral com $27 \% "$. Os mesmo autores também esclarecem que o modal marítimo também se tornou um elo para a multimodalidade dos transportes, permitindo aperfeiçoar o transporte global e integrar toda a cadeia logística, fomentando as relações comerciais no mundo.

As características do modal marítimo, de acordo com Nunes (2007) são: a cabotagem que é um tipo de navegação que ocorre entre portos ou pontos do território brasileiros, usando a via marítima; a navegação inferior que é uma navegação que ocorre por hidrovias interiores ou lagos seja num percurso nacional ou internacional e; a navegação de longo curso que é ocorre entre portos brasileiros e estrangeiros.

\title{
5.1.2 Transporte aéreo
}

Assim como o marítimo, o portal "aprendendo a exportar" da Secretaria de Comércio Exterior Brasileiro (SECEX), na seção planejamento a exportação e subseção planejamento estratégico, afirma que o transporte aéreo é utilizado com uma maior urgência e é considerado o transporte mais eficaz.

Ribeiro e Ferreira (2002) afirmam que essa modalidade aérea apresentou uma demanda crescente de usuários, por outro lado, o valor de seu frete é considerado o mais elevado, porém o que compensa o uso desse transporte é o deslocamento porta a porta por ter se tornando mais reduzido, principalmente em trajetos distantes. Os autores também esclarecem que esse tipo de transporte é utilizado para transportar cargas de alto valor unitário (relógio, artigos de moda, etc) e perecíveis (frutas, flores, medicamentos, e outros).

Ballou apud Ribeiro e Ferreira (2002) afirma que o modo aéreo apresenta os serviços contratuais e próprios. E, que o serviço aéreo é oferecido em sete tipos, que são: linhas-tronco domésticas regulares, cargueiras (apenas para cargas), suplementares (chartes - fretamento, não 
tendo programação regular), regionais (substitui rotas domésticas), taxí aéreo (transporte de cargas e passageiros entre centro de cidade e grandes aeroportos) e, internacionais (transporte de cargas e pessoas).

Nascimento (2007) afirma que nesse mesmo ano observando o comércio exterior brasileiro, muitos imaginavam que o transporte aéreo era pouco utilizado, pois os dados entre o período de janeiro de 2006 a abril de 2007 mostravam que o transporte aéreo ocupava a segunda posição dos transportes mais usados, através do transporte marítimo. Mas, autor ressalta que analisando os dados em percentual de mercadorias importadas, a diferença era mínima, sendo de $0,20 \%$, ressaltando a importância dessa modalidade de transporte no envio de produtos de alto valor agregado, assim como, nas exportações onde o modal aéreo ocupava a terceira posição, entre o período de janeiro de 1996 a abril de 2007.

Ribeiro e Ferreira (2002) justifica que apesar do transporte aéreo ser considerado o transporte com maior valor de frete, as suas vantagens são compensatórias, como: a velocidade elevada; a distância alcançada; a segurança contra roubos, danos e extravios e; a redução de custos em estoque. Mas, tendo como desvantagens: o próprio valor do frete; tempos de coleta e entrega da mercadoria; manuseio no solo e; as dimensões físicas dos porões dos aviões.

Por fim, diferentemente do marítimo, o documento que formaliza o contrato aéreo é conhecido como Conhecimento Aéreo ou em Inglês Airway Bill - AWB (SEGRE, 2012, p. 145).

\subsubsection{Transporte ferroviário}

Sobre o modal ferroviário, o portal "aprendendo a exportar" da Secretaria de Comércio Exterior Brasileiro (SECEX), na seção planejamento a exportação e subseção planejamento estratégico, afirma que o transporte ferroviário acontece através de vagões tracionados por locomotivas que, sobre trilhos, percorrem um trajeto sem muita possibilidade de flexibilidade. Salientando que essa modalidade de transporte não é muito utilizada pelos exportadores brasileiros por apresentar limites na malha ferroviária. E, o Brasil apresenta acordos bilaterais nessa modalidade de transporte com a Argentina, Bolívia e Uruguai.

Ribeiro e Ferreira (2002) esclarecem que o transporte ferroviário no Brasil era usado para transportar grandes tonelagens de produtos por trajetos de longas distâncias, como minério (ferro e manganês), derivados de petróleo e cereais em grão, carvões minerais e outros, sendo transportados em granel.

Ballou apud Ribeiro e Ferreira (2002) afirma que o transporte ferroviário é dividido em duas formas de serviço, o transportador regular e o privado, definindo transportador regular como aquele que presta serviço para qualquer usuário, voltado para termos regulamentados em aspectos econômicos e segurança. E, o transportador privado é aquele que pertence a um usuário particular, utilizando o serviço com exclusividade.

No que se refere aos custos desse tipo de transporte, Ribeiro e Ferreira (2002) afirmam que o modal ferroviário apresenta alto custo fixo, principalmente em equipamentos, vias férreas, terminais e outros, porém, o custo variável desse transporte é baixo. $O$ autor também afirma que apesar do custo variável do transporte ser baixo, esse tipo de transporte não é muito utilizado no Brasil, como o transporte rodoviário, justificando que isso ocorre pelo fato de existirem problemas de infraestrutura e investimentos. 
Já Nascimento (2007) informa que esse tipo de transporte ainda é precário e o modal ferroviário brasileiro é limitado, tendo apenas forma efetiva com a Argentina, Bolívia, Chile, Paraguai e Uruguai. De acordo com o autor, no ano de 2007 o modal ferroviário apresentou um percentual de participação de 0,26\% nas exportações, transportando 0,14\% das mercadorias, ocupando o sexto lugar no ranking dos modais mais usados no mesmo ano.

Diante dos ensinamentos de Nascimento (2007) o transporte ferroviário é considerado um dos tipos mais adequados para mercadorias de baixo valor agregado e em grandes quantidades, por outro lado, esse tipo de transporte não é eficiente em agilidade, por causa do seu trajeto não apresentar flexibilidade. Porém, o autor evidencia que o Brasil poderia explorar melhor esse tipo de transporte, sendo o mais favorável em longas distâncias.

Por fim, segundo o portal "aprendendo a exportador" o documento que formaliza o contrato no transporte ferroviário é conhecido como Conhecimento de Embarque Ferroviário.

\subsubsection{Transporte rodoviário}

Por último, o portal "aprendendo a exportar" da Secretaria de Comércio Exterior Brasileiro (SECEX), na seção planejamento a exportação e subseção planejamento estratégico, afirma que o modal rodoviário é caracterizado pela facilidade de entrega da mercadoria, assim como, a facilidade e simplicidade desse meio de transporte em casos de envio urgente de mercadorias. E, o Brasil possui o convênio sobre transporte internacional terrestre com a Argentina, Paraguai, Uruguai, Bolívia, Chile e Peru, regulamentando a movimentação de cargas por rodovias e questões aduaneiras.

Nascimento (2007) esclarece que o modal rodoviário no Brasil apresenta um quadro precário que é ocasionado por elevados custos de manutenção e perda de tempo nos processos logísticos, porém é um transporte bastante usado no cenário interno brasileiro, apresentando entre janeiro de 2006 a abril de 2007 uma participação de 6,48\% nas importações brasileiras e $5,30 \%$ em quantidade de mercadorias transportadas, ocupando o terceiro lugar no ranking dos transportes voltados a importação e, nas exportações ocupando o segundo lugar.

Sobre as vantagens do transporte rodoviário, Nascimento (2007) afirma que podemos encontrar a agilidade no acesso as cargas, um menor manuseio da carga, assim como, uma menor exigência de embalagem, entre outros. Sendo também um modal que pode ser facilmente interligado com os outros tipos de modais, favorecendo a intermodalidade e a multimodalidade. Por outro lado, o autor evidencia que apesar das vantagens, esse tipo de transporte vem perdendo competitividade por ser desfavorável a longas distâncias e, em alguns momentos apresentar um valor de frete elevado. Nessa modalidade de transporte os veículos mais usados são os caminhões tradicionais, as carretas, e outros.

Já Ribeiro e Ferreira (2002) afirmam que esse tipo de transporte é um dos mais expressivos no cenário brasileiro, pelo fato que após a década de $50 \mathrm{com}$ a construção e a pavimentação de rodovias e a instalação de indústrias automobilísticas, fizesse com que o transporte rodoviário passasse a ser um dos mais procurados.

Sobre o valor do frete, Ribeiro e Ferreira (2002) esclarecem que esse tipo de transporte apresenta preços de fretes mais elevados do que os outros, como o ferroviário, sendo um transporte recomendado para produtos agrícolas a granel que apresentam custos baixos. Já em 
relação aos serviços, os autores afirmam que além de ocorrer à distinção entre transportadores regulares e de frotas privadas, ainda existem os transportadores contratados que são os transportadores utilizados por um número limite de usuários a partir de contratos de longa duração e, os isentos que são aquelas que oferecem um serviço aos clientes que maneira a reduzirem seus custos com problemas administrativos ligados à frota própria, manutenção e outros.

Por fim, segundo o portal "aprendendo a exportador" da Secretaria de Comércio Exterior Brasileiro (SECEX), o documento que formaliza o contrato no transporte rodoviário é conhecido como Conhecimento de Transporte Internacional e deve ser assinado tanto pelo exportador, quanto pelo importador.

\section{DIPLOMAS LEGAIS APLICÁVEIS AOS CONTRATOS DE TRANSPORTE}

Nesse capítulo serão discutidos os diplomas legais que podem ser aplicados aos diversos contratos de transporte na modalidade marítima, assim como, suas particularidades.

\section{CÓDIGO DE DEFESA DO CONSUMIDOR}

Sobre a ótica da proteção da relação de consumo no Brasil, Almeida $(2009$, p. 1) esclarece que o consumo é parte indissociável do cotidiano do ser humano, pois todos nós somos consumidores, independentemente da classe social e renda.

As relações de consumo são bilaterais, tendo numa ponta o fornecedor - que pode tomar a forma de fabricante, produtor, importador, comerciante e prestador de serviço -, sendo aquele que se compromete a fornecer bens e serviços a terceiros, e, na outra ponta, está o consumidor, dependente do fornecedor dos bens ou serviços que tende a atender suas necessidades (ALMEIDA, 2009; NUNES, 2012; MARSAIOLI e FILHO, 2013).

Almeida (2009, p. 2) caracteriza relação de consumo, tendo por base os contratos bancários, financeiros, de seguro, leasing ou arrendamento mercantil, fornecimento de serviços em geral, compra e venda e a respectiva promessa, hospedagem, transporte, e outros. Um ponto importante exposto pelo autor é que as relações de consumo com o tempo deixaram de ser relações pessoais e diretas, para serem operações impessoais e indiretas, em que não importa o fato de não se ver ou conhecer o fornecedor.

As relações de consumo sofreram modificações que culminaram na percepção de que o consumidor estava desprotegido e necessitava, portanto, de resposta legal protetiva (ALMEIDA, 2009). Nesse novo tipo de mercado de consumo, a vulnerabilidade de consumidor passa a ser evidente e demanda que o Estado interfira nesse tipo de relação contratual eficazmente.

Sidou apud Almeida (2009, p. 3-4) afirma que o que deu grande dimensão ao que diz respeito a proteção do consumidor foi o crescente desenvolvimento do comércio e a ampliação da publicidade, que juntas resultaram no fenômeno de sociedade de consumo. A produção em massa precisava, aos olhos dos empresários, ser absorvida pelo mercado, por isso o cidadão passou a ser tratado como um consumidor em potencial em todos os minutos de sua vida, com a frequente exposição publicitária onde quer que estivesse. 
O reconhecimento de que o consumidor estava desprotegido em termos educacionais, informativos, materiais e legislativo determinou maior atenção para o problema e o aparecimento de legislação protetiva em vários países (ALMEIDA, 2009, p. 4). Por isso, esclarece que a proteção jurídica do consumidor não é assunto de respeito a um único país, pois se trata de um tema supranacional, abrangendo todos os países tanto desenvolvidos como em processo de desenvolvimento.

Os primeiro passos dados para a proteção do consumidor surgiram através da Resolução n. 2.542, de 11 de dezembro de 1969, proclamada pela Declaração das Nações Unidas sobre o progresso e desenvolvimento social. Em 1973, a Comissão de Direitos Humanos da ONU, reconheceu os direitos fundamentais e universais do consumidor. Porém, o passo mais importante para a proteção do consumidor ocorreu em 1985 pela Resolução n. 39/248/85, de 16 de abril de 1985, através da qual a ONU cuidou detalhadamente do tema, criando normas sobre a proteção do consumidor e, após isso, o consumidor foi visto como vulnerável em termos econômicos, educacionais e aquisitivos, sendo necessária a proteção do mesmo. Essas normas ainda reforçam a ideia de que o governo também faz parte desse processo.

Outro ponto importante destacado pelo autor é que a ONU tem por finalidade a cooperação internacional, ou seja, as diretrizes de proteção ao consumidor encorajam a troca de informação e aspectos dos produtos e programas de maneira unificada, de forma que, não irá acarretar em uma grande variação de um país para outro (ALMEIDA, 2009, p. 6).

Sobre o aspecto histórico do CDC no Brasil, Almeida (2009, p. 9) afirma que o tema no território brasileiro é relativamente novo. $O$ primeiro órgão relativo a questões do consumidor no Brasil, o PROCON, Grupo Executivo de Proteção e Orientação ao Consumidor de São Paulo surgiu em 1978 através da Lei n. 1.903, do mesmo ano. No âmbito federal, só foi criado em 1985 o Conselho Nacional de Defesa do Consumidor através do Decreto n. 91.469, posteriormente substituído pela Secretaria Nacional de Direito Econômico (SNDE).

O ponto mais importante para o código brasileiro foi dado em 1985, com a criação da Lei n. 7347 em 24 de julho de 1985 que focava a ação civil pública de responsabilidade por danos causados ao consumidor. Na mesma data foi assinado o Decreto Federal n. 91.469 que tinha como objetivo criar o Conselho Nacional de Defesa do Consumidor (CNDF), com a função de assessoriamento ao Presidente da República na formulação e execução de políticas voltadas à defesa do consumidor. Porém, a vitória mais importante ocorreu em 5 de outubro de 1988, com a inserção de quatro dispositivos específicos sobre o tema na Constituição da República.

A ideia central de tais dispositivos é: A defesa do consumidor, na forma de lei, como dever do Estado (art. 5o, XXXII); a competência do Estado legislar sobre os danos causados ao consumidor (art. 24, VIII); a defesa do consumidor demanda a intervenção do Estado na economia (art. 170, V); e, a edição do Código de Defesa do Consumidor pelo art. 48 do ato das Disposições Constitucionais Transitórias (ALMEIDA, 2009, p. 10).

No que diz respeito às alterações do Código de Defesa do Consumidor, Almeida (2009, p. 11-12) afirma que desde sua vigência em 1991, o CDC foi alterado por cinco leis e várias Medidas Provisórias. $\mathrm{O}$ autor ainda evidencia que as alterações realizadas no CDC foram para beneficiar 0 consumidor, caracterizadas ora por correção do texto, para ampliação de suas garantias, ora por tratamento mais severo às práticas abusivas, asseguradas na Medida Provisória n. 550, de 08 de julho de 1994, que foi reeditada. 
Com isso, a Política Nacional de Relação de Consumo tem como alguns princípios: a vulnerabilidade do consumidor ${ }^{8}$, a presença do Estado $^{9}$ e a harmonização de interesses ${ }^{10}$. Conforme Almeida (2009, p. 35-36) pode-se observar CDC como um microssistema jurídico interdisciplinar formado por normas jurídicas num mesmo corpo legislativo, objetivando a defesa do consumidor nos planos legais e materiais. Assim como, a sua estrutura composta pelos direitos básicos do consumidor (art. 6ㅇ) , seguido das normas do fornecedor para entregar produtos e serviços com garantia de qualidade e reparação de danos (arts. 8, 9 e 10) e a responsabilidade civil diante de vícios recorrentes de serviços ou produtos (arts. 12 a 28). Tendo assim, uma lógica que fundamente a proteção ao consumidor.

Outro aspecto importante para a utilização do CDC é a definição de consumidor, que apesar de prevista legalmente, provoca, até hoje, grande divergência doutrinária. Filomeno apud Almeida (2009, p. 37) entende que "é todo indivíduo que se faz destinatário da produção de bens, seja ele ou não adquirente, e seja ou não, a seu turno, também produtor de outros bens".

Porém, o autor afirma que a melhor definição seria a de Herman Benjamin, exposta como sendo "todo aquele que, para seu uso pessoal, de sua família, ou dos que se subordinam por vinculação doméstica ou protetiva a ele, adquire ou utiliza produtos, serviços, ou quaisquer outros bens ou informação colocados a sua disposição por comerciantes ou por qualquer outra pessoa natural ou jurídica, no curso de sua atividade ou conhecimento profissionais" (ALMEIDA, 2009, p. 37-38). (sic)

Além dessas definições, podemos encontrar a definição de consumidor disposta no próprio CDC como "toda pessoa física ou jurídica que adquire ou utiliza produto ou serviço como destinatário final”. O CDC ressalta também a figura do consumidor por equiparação que, apesar de não se enquadrar no conceito de consumidor, será tratado como tal.

Assim como, a definição de consumidor imposta pelo CDC cabe-se também a definição de fornecedor como "toda pessoa física ou jurídica, pública ou privada, nacional ou estrangeira, bem como os entes despersonalizados, que desenvolvem atividades de produção, montagem, criação, construção, transformação, importação, exportação, distribuição ou comercialização de produtos ou prestação de serviços" (CDC, art. $\left.3^{\circ}\right)$.

Conforme Darbilly (2013) a discussão do uso do CDC em contratos marítimos de mercadorias envolve grandes interesses, onde se têm numa ponta os exportadores, importadores e demais embarcadores, destinatários e segurados, tendo com a aplicação do CDC uma maior proteção jurídica e na outra, armadores e NVOCC's ${ }^{11}$.

Porém, a teoria do uso do CDC nos contratos de transporte marítimos de mercadorias perdem forças quando conforme Seixas (2013) tem como objeto de relação de contrato o transporte marítimo de bagagens atribuído à aplicação do CDC, onde o produto fica fora da cadeia de produção. Ou seja, o ato de retirar o produto da cadeia produtiva faz com que a

\footnotetext{
${ }^{8}$ Tem como característica o reconhecimento da fragilidade do consumidor diante da relação de consumo.

${ }^{9} \mathrm{~A}$ influência do Estado na relação de consumo dando suporte a parte mais fraca (o consumidor).

10 Caracteriza-se pelo processo de fornecimento de bens e serviços do fornecedor para o cliente, através dos interesses de ambos, em uma relação harmoniosa.

11 NVOCC - Non Vessel Operator Common Carrier, em português 'transportador não proprietário do navio' ou na forma mais simples, agente de carga.
} 
aplicabilidade do CDC nos contratos de mercadorias perca forças, por o produto ainda permanece na cadeia de produção.

Damásio (2009); Novais apud Moreira (2005) e Castro Jr. (2007) afirmam que a aplicação do CDC é proteger a cidadania e estabelecer justiça, de maneira que garantirá o cumprimento da lei pelos beneficiados numa relação contratual. E, diante de um contrato de prestação de serviço, deve-se valer o direito do consumidor, de forma que ninguém seja prejudicado.

Marsaioli e Filho (2013) apresentam opinião contrária, pois em determinados casos as empresas utilizam os serviços dos NVOCC que na cadeia produtiva não são considerados consumidores finais, especialmente quando contratados no exterior. Assim como, a insegurança jurídica e os custos, tornando o país menos atrativo para investimentos estrangeiros. Porém, os mesmos autores e Darbilly (2013) ressaltam os casos de pessoas físicas que usam o transporte marítimo para realização de mudanças, sendo cabível o CDC.

Por fim, Darbilly (2013) e Moreira (2005) esclarecem que diferentemente do que ocorre no marítimo, o transporte aéreo é regido de forma pacificada pelo CDC.

Diante da ainda corrente aplicação de códigos diferentes do CDC aos casos concretos, se faz necessário conhecer um pouco dos demais diplomas legais aplicados aos contratos de transporte marítimo de mercadoria, bem com suas particularidades. Desta forma, será possível perceber a influência de cada dispositivo legal nessa modalidade de transporte.

\section{CÓDIGO COMERCIAL VERSUS CÓDIGO CIVIL}

No que trata o Código Comercial, podemos perceber que a diferença desse diploma legal para o Código de Defesa do Consumidor é que o seguinte diploma é regulamentado pela Lei. $\mathrm{n}$. 556 , de 25 de junho de 1850.

Conforme Miranda apud Aguiar (2003) o Código Comercial de 1850, foi o primeiro em âmbito nacional a regular o transporte de pessoas. Porém, esse Código, em janeiro de 2003, teve a sua primeira parte revogada, totalizando mais de 400 artigos revogados, com a entrada em vigor do Código Civil de 2002. Isto se deu em razão de o Código Civil adotar a teoria italiana da empresa, ao passo o Código Comercial era/é baseado na teoria francesa dos atos de comércio. Teoria esta que se encontra obsoleta.

O comércio iniciou-se devido às produções e atividades de consumo, sendo considerado em seu princípio apenas para sobrevivência. Focando na troca de excedentes com o objetivo de gerar uma melhor qualidade de vida, entre os considerados detentores dos bens. Com o tempo, houve-se a necessidade de trocar as mercadorias não mais por outras mercadorias mas por moeda, com o intuito de facilitar a circulação de riquezas.

É importante ressaltar também que o comércio existe desde a antiguidade. Como exemplo disso, podem ser mencionados os povos fenícios, que tiveram um grande destaque no exercício dessa atividade.

Anteriormente à formulação do Código Comercial brasileiro, cuja segunda parte ainda está em vigor, foram utilizados Códigos historicamente conhecidos como o Código de Manu (Índia) e o Código de Hamurabi (Babilônia), nos quais já haviam dispositivos relacionados às atividades do comércio. 
Tal qual ocorrem nas relações de consumo, reguladas pelo Código de Defesa do Consumidor, também as relações comerciais, reguladas ainda, em parte, pelo Código Comercial, sofrem a interferência do Estado. Isto pode ser observado na fixação de competência para legislar sobre os danos ocorridos nesse diploma legal e sobre as questões econômicas, sempre passíveis de alterações com a vigência de novas normas.

Como o próprio nome afirma, o presente diploma trata de questões comerciais. O Código seguiu diretrizes de duas ordenanças, que são a de março de 1673, que tinha como referência o comércio terrestre e vigorou por mais de 300 anos, regulamentado pelo Código Comercial Francês; e a Ordenança da Marinha, de 1681, que regulamentava vários contratos do Direito Marítimo.

O Código Comercial brasileiro, bem como o Código belga (1811), espanhol (1829) e português (1833) seguiram características francesas, ao adotar a teoria dos atos de comércio. A França serviu de parâmetro para outros países por ter sido pioneira. Lá surgiu o primeiro Código Comercial, organizado por Napoleão em 15 de Setembro de 1807.

Um aspecto importante é que diferentemente do CDC que é aplicável para contratos entre consumidor e fornecedor, o Código Comercial é aplicável para contratos onde nenhuma das partes é definida como consumidor, ou seja, nenhuma das partes é vulnerável.

Conforme Aguiar (2012), o Código Comercial de 1850 trata de contratos de transporte marítimos e do Direito Marítimo nos artigos 457 a 796, presentes em sua segunda parte, que foram mantidos em vigor pela interpretação a contrario sensu do artigo 2.045 do Código Civil. Assim como, os artigos 730 a 756 que tratam das obrigações do transportador, objetivando o transporte e a entrega da coisa/mercadoria. E o Título VI, Capítulo I do Código, que trata dos contratos de fretamento.

O artigo 566 do Código Comercial esclarece contrato de fretamento da seguinte forma:

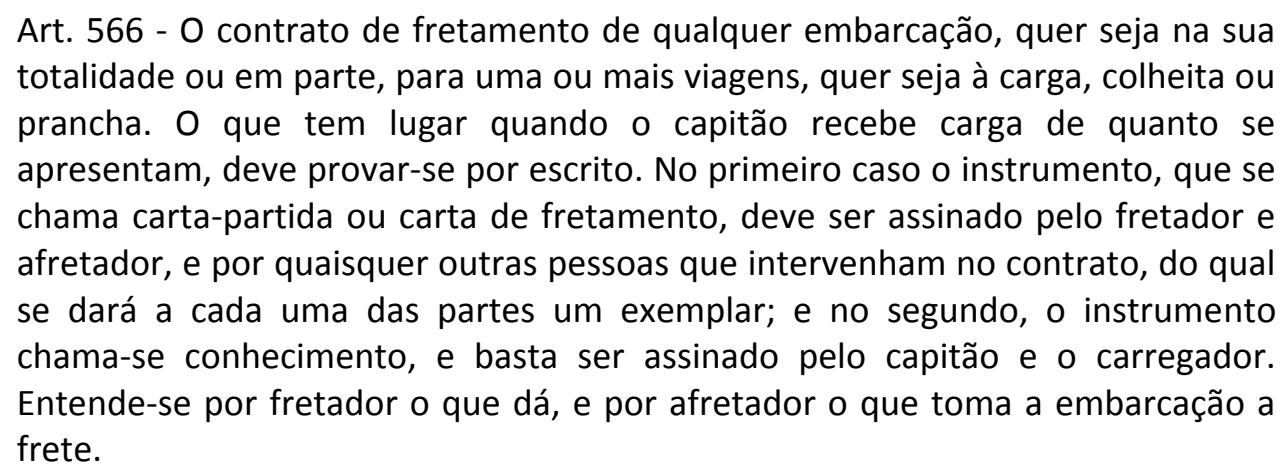

Para esclarecer a ideia de contrato de fretamento teríamos como exemplo, o contrato de fretamento de navio para passeio ou uso profissional. Ou seja, quando o proprietário do navio, freta o seu navio para outro indivíduo. De maneira que, esse fretamento é dado através de um contrato, no qual o fretador irá utilizar o navio para uso próprio, independente de ser apenas para uso pessoal ou também pra uso profissional, acarretando em lucro. Porém, com o comprometimento de entregar o navio para seu proprietário da forma como recebeu. 
Assim como o Código Comercial e o Código de Defesa do Consumidor, o Código Civil também apresenta suas particularidades. É um diploma legal usado em contratos em que as partes envolvidas não são ambas consideradas empresárias.

O atual Código Civil Brasileiro é regulamentado pela Lei n. 10.406 de 10 de janeiro de 2002. Assim como o Código Comercial, também trata das atividades relacionadas aos contratos de transporte, em seu Capítulo XIV. Dividido em três partes, sendo que na primeira se encontram as disposições gerais de contrato. Na segunda as questões que envolvem os contratos de transporte de pessoas. E, na terceira, o transporte de coisas. Além, desse Capítulo, o diploma legal trata no Capítulo XV sobre seguro, também dividido em três partes que abordam respectivamente, disposições gerais, seguro de danos, seguro de pessoas.

"O novo Código Civil se dispôs a tratar de matéria que nossa legislação civil antiga estava prevista em dispositivos esparsos" (AGUIAR, 2003).

Segundo Aguiar (2003) quando se trata de contrato de transporte com a possibilidade do uso do Código Civil, é necessário o envolvimento de dois personagens: o transportador e o passageiro. Sendo esse passageiro aquele que adquire a passagem e é transportado, ou seja, que a usa em sua própria posse. Porém, podendo ocorrer a intervenção de um terceiro personagem, adquirente da passagem e que esteja ligado ao passageiro.

Além desses dois personagens, Aguiar (2003) esclarece que deve-se existir a translação no contrato de transporte, sendo a transferência de um lugar para o outro. Assim como, a característica comutativa, que é, desde o momento de celebração do contrato, a definição das responsabilidades de cada parte envolvida. $E$, o mesmo autor evidencia que o que diferencia um contrato de transporte de pessoas ou coisas não é a sua causa, mas, o objeto do contrato. Atribuindo-se também a característica da bilateralidade, ou seja, obrigações recíprocas.

Conforme Aguiar (2003) no art. 732 do Código Civil, podemos encontrar que a aplicabilidade do Código nos contratos de transporte pode ser permitida, desde que não contrariem as suas disposições, e os preceitos presentes na legislação especial e de Tratados e Convenções Internacionais.

Art. 732, CC: “Aos contratos de transporte em geral são aplicáveis, quando couber, desde que não contrariem as disposições desse Código, os preceitos constantes da legislação especial e de Tratados e Convenções Internacionais".

E, em relação ao CDC e o Código Civil, no que diz respeito a qual diploma legal utilizar, o autor afirma que ambos podem ser usados. Porém, um complementando o outro, com a justificativa de que, quando tratar-se de relação de consumo deve-se optar pelo CDC e, quando essa relação não estiver na esfera do consumo, identificando que as partes não são consumidorfornecedor, usa-se o Código Civil.

Um exemplo que justifica a opinião do autor são os contratos de transporte de pessoas, como o transporte coletivo, pois a partir do momento em que o passageiro utiliza o transporte público, ele está participando de um contrato, mesmo que esse contrato não seja escrito ou assinado pelo mesmo. De maneira que, o passageiro recebe um benefício bem maior em relação ao valor da passagem paga, sendo um valor pequeno. E, o motorista tem a responsabilidade de transporta-lo até o destino pretendido. $O$ autor defende que essa relação é regulada pelo Código Civil. Porém, na prática está relação é considerada de consumo, pois, em um lado encontra-se o 
consumidor - passageiro e em outro o fornecedor de serviços - empresa a qual o motorista é empregado e está representando naquela ocasião. Por outro lado, caso o motorista tivesse algum confronto com um passageiro específico, tornando-se algo pessoal, a seguinte situação seria regulada pelo Código Civil.

\section{REGRAS DE YORK-ANTUÉRPIA}

Sobre os tratados e convenções internacional é notável que existem diversos. Tais como, segundo Pereira e Cazzaro (2012), as Regras de Hamburgo de 1978 e a Regra de Haia de 1024, que tratam do Conhecimento de Carga - Bill of Lading. Além dessas regras, têm-se as Regras de York-Antuérpia, que conforme Gibertoni (2005, p. 213) explica, além de tratar dos instrumentos contratuais, como o Conhecimento de Carga, também tem como objetivo pactuar e disciplinar encargos em caso de acidentes marítimos.

Gibertoni (2005) expõe que a Regra de York-Antuérpia é um conjunto de 7 regras alfabéticas (de $A$ a G), que define o ato de uma avaria grossa, assim como, seus fundamentos, sua natureza, e outras atribuições. Essa regra é utilizada em contratos de transporte marítimo em casos de acidentes que ocorram avarias.

Gibertoni (2005, p. 214) esclarece que as Regras de York-Antuérpia definem avaria, principalmente, avaria grossa como: "Um ato se caracteriza como avaria grossa quando, e somente quando, implicar em um sacrifício ou despesa extraordinário, internacional e razoavelmente feito para a segurança comum e no sentido de preservar de um perigo os bens envolvidos na mesma expedição marítima". (sic)

Sobre as responsabilidades, Gibertoni (2005, p. 216) afirma que em relação aos prejuízos decorrente das avarias, deve ser rateado o valor entre todos os interessados, tais como navio, carga e frete, que estão dispostos no art. 763 do Código Comercial e na própria regra. E, a quantia rateada é denominada de valor contribuinte.

Vale ressaltar que, as regras de York-Antuérpia são utilizadas ao se tratar de contrato de transporte marítimo internacional. Quando se trata de navegação de cabotagem, usa-se o Código Comercial (GIBERTONI, 2005, p. 216).

\section{ANÁLISE JURISPRUDENCIAL}

Nesse capítulo serão abordadas as análises das jurisprudências retiradas do site do STJ Superior Tribunal de Justiça. Tais decisões jurisprudenciais refletem a divergência doutrinária existente acerca da aplicação ou não do CDC nos contratos de transporte de mercadorias.

Resp. ${ }^{12} 286.441$ / RS, relatado pelo Ministro Antônio de Pádua Ribeiro, da terceira turma, julgado em 07 de novembro de 2012.

Este caso versou sobre uma ação indenizatória, em um contrato de transporte marítimo de mercadorias no qual se discutiu a aplicação do Código de Defesa do Consumidor. Discutiu-se ainda a importância ou não da análise da definição de consumidor para o julgamento adequado

12 Recurso Especial. 
do caso, tendo em vista a consumação do transporte e da chegada da mercadoria no local de destino, atribuindo-se caráter de consumo, realizado entre os transportadores (Transroll Navegações S/A Seaways Sul e Agência Marítima Riograndense Ltda.) e uma pessoa jurídica (Faprol Indústria de Alimentos Ltda.).

A íntegra do acordão mostra que a decisão dos ministros não foi unânime. Dos cinco (05) votos, com três (03) a favor e dois (02) contra a aplicação do CDC. Sendo a favor, os ministros (as) Carlos Alberto Menezes Direito, Nancy Andrighi e Castro Filho, contra os ministros (as) Antônio de Pádua Ribeiro e Ari Pargendler.

O que levou à demanda judicial foi o fato de que a empresa transportadora contratada pela Faprol Indústria de Alimentos Ltda., para transportar $3.800 \mathrm{Kgs}$ de coalhos alimentícios em pó, do porto de Imbituba/SC com destino ao porto de Hotterdan/Holanda, não tomou as devidas providências para evitar a umidade em excesso, fazendo com que a mercadoria chegasse imprópria para comercialização.

O voto do Ministro Carlos Alberto Menezes Direito foi a favor da Faprol Ltda., ou seja, a favor da aplicação do CDC ao caso, justificando-o pelo fato de o transporte de mercadoria ter sido realizado com sucesso para o porto de Hotterdan, terminando assim a relação entre a Faprol e as transportadoras, consideradas, pelo mesmo, como de consumo. Para ele não seria importante conhecer o que seria feito com a mercadoria pela empresa alemã, destinatária final fática, caracterizada como parte no contrato de compra e venda da mercadoria transportada. Porém, a mercadoria chegou com umidade, tornando-a imprópria para comercialização.

O ministro fundamentou seu voto apresentando a definição do art. 2o do CDC, sendo "consumidor toda pessoa física ou jurídica que adquire ou utiliza produto ou serviço como destinatário final". Compreendeu que a autora, no caso, não seria apenas intermediadora, mas também destinatária final, que lhe garantiria a condição de consumidora.

Esse voto foi seguido pelos votos dos (as) ministros (as) Nancy Andrighi e Castro Filho. A justificativa de Nancy para a aplicação do CDC deu-se ao fato de ocorrer um contrato entre um fornecedor de bens e um consumidor, tendo por base uma visão mais objetiva do art. 20 do CDC, apresentado pelo ministro Carlos Alberto, justificando a divergência doutrinária e jurisprudencial. E, Castro Filho apoiou esse posicionamento afirmando que apesar de tratar-se de um contrato com objetivo econômico, a natureza da relação contratual em análise era entre a autora e as résrecorridas, tendo como objeto a prestação do serviço de transporte de carga, deixando de lado a esfera de fins econômicos, ou seja, a destinação final econômica. Defendeu que a recorrente seria destinatária final do serviço de transporte prestado, consequentemente, consumidora.

Resp. 236.755 / SP, relatado pelo Ministro César Asfor Rocha, da quarta turma, julgado em 08 de maio de 2001.

O Recurso Especial n. 236.755 tratou de uma situação de responsabilidade civil oriunda de um contrato de transporte aéreo internacional em que houve extravio de carga e, para resolvêlo, necessário decidir qual norma a ele seria aplicada. Através do disposto no Código de Defesa do Consumidor, o evento ocorrido em vigência, teve como objetivo afastar a indenização tarifada. 
A íntegra do acordão expõe que houve dois (02) votos, sendo, de forma unânime, a favor da aplicação do CDC, proferidos pelos ministros César Asfor Rocha (Relator) e Aldir Passarinho Junior.

O voto do ministro César Asfor Rocha foi justificado com base na responsabilidade da companhia aérea por extravio da mercadoria que era o objeto do contrato de transporte. Porém, a autora/recorrida solicitou a reparação integral do dano, ao contrário da ré/recorrente, que buscou a adoção da indenização tarifada, calculando o valor em cima do peso do objeto transportado, em virtude das disposições contidas na Convenção de Varsóvia.

O ministro esclareceu em seu voto que já foi a favor da não aplicabilidade do CDC nesses casos, citando os seguintes precedentes: RESP 5729/DF, DJ 23/06197, Rel. p/Acórdão Ministro Fontes de Alencar; RESP 32903/SP, DJ 23/09196, Relator Ministro Sálvio de Figueiredo Teixeira e outros. Mas, que diante de debates desencadeados durante esse caso, firmou seu posicionamento a partir do voto-vista proferido no Resp. n. 171.506/SP, concedendo a reparação integral do dano na luz do CDC.

Já o ministro Aldir Passarinho Junior, justificou seu voto apenas confirmando a decisão do ministro-relator César Asfor Rocha, fundamentando a sua decisão através do caso Resp. n. 231.456/SP. Acompanhando o voto do ministro relator, conheceu o recurso, mas negou-lhe provimento.

Resp. ${ }^{13} 355.717$ / RJ, relatado pelo Ministro Raul Araújo, da quarta turma, publicado em 27 de junho de 2014.

O Agravo em recurso especial n. 355.717 / RJ, relata a situação de importação de mercadorias por uma empresa sediada na China para uma empresa brasileira. Porém, a quantidade da mercadoria que chegou ao território nacional foi inferior à quantidade acordada entre as partes. Com isso, a empresa brasileira entrou com um processo judicial contra a empresa chinesa, alegando tratar-se de uma relação de consumo, devendo ser aplicado o CDC.

A empresa brasileira (Madeprego Indústria e Comércio Ltda.) alegou que a empresa chinesa, tinha como obrigação agir com máxima diligência no cuidado das mercadorias. Porém, durante a análise do caso, ocorreram algumas opiniões controversas à situação examinada.

Em relação à aplicação do Código de Defesa do Consumidor, o tribunal que julgou o caso, afastou a possibilidade de utilização do diploma legal, alegando que não se tratava de uma relação de consumo porque a empresa Madeprego Indústria e Comércio Ltda. Não se enquadrava no conceito de consumidor, apesar do fato ocorrido ter sido em função do número inferior das mercadorias enviadas para a empresa brasileira. Isso se deveu, entre outras razões, a atribuição que a mercadoria iria ter no mercado interno, fazendo parte integrante da cadeia produtiva da empresa nacional, o que não caracterizaria a não destinação final econômica do produto.

Sobre a indenização, o tribunal entendeu que não ficou configurado o dever de indenizar por parte da empresa chinesa, de forma que, a atribuição dada à ré foi caracteriza como personagem de agente marítimo, exercendo atividade meramente mandatória.

${ }^{13}$ Agravo em Recurso Especial. 
Assim, não há que se falar em responsabilidade do agenciador pelos atos do transportador, que, de qualquer forma, transportou com segurança e eficiência toda mercadoria que Ihe foi entregue. Entregou autora, incólume, toda mercadoria que recebeu da vendedora. No caso, com visto, foi a vendedora chinesa que embarcou quantia menor que ajustada (e-STJ, fls. 316/317). (sic)

Com isso, não foi aplicado o CDC nesse caso, sendo o diploma aplicado na decisão o Código de Processo Civil.

Resp. 302.212 / RJ, relatado pelo Ministro Castro Filho, da terceira turma, julgado em 27 de junho de 2005.

A Ementa do caso trata de recurso especial interposto com objetivo indenizatório, em razão de danos de avaria na mercadoria, ocorrido na consecução de contrato de transporte de mercadorias através do modal marítimo, tendo sido solicitada a aplicação do Código de Defesa do Consumidor (CDC) ao caso.

A demanda judicial foi iniciada pela empresa Sul América Companhia Nacional de Seguros, que propôs uma ação contra a Clipper Shipping Limited, a fim de receber um ressarcimento da segurada Editora o Dia Ltda., pelo transporte de 1.007 bobinas de papel jornal, vindas do Canadá, transportadas por navio do réu, sofrendo avarias.

Durante o julgamento, a empresa ré foi condenada a pagar $\mathrm{R} \$ 45.064,47$, sendo esse valor corrigido monetariamente desde 06/12/96, ainda acrescido de juros. O Tribunal de Justiça do Rio de Janeiro negou provimento ao recurso, afastando a obrigação de pagamento, por ter se tratado de uma avaria grossa e que deveria se aplicar o prazo prescricional de cinco anos previsto no art. 27 do CDC.

Diante do previsto no art. 27 do CDC, como prazo prescricional, a empresa ré ajuizou recurso especial, alegando violação ao artigo 449, inciso II, do Código Comercial, que apresenta um ano como prazo prescricional, por motivo do colegiado ter entendido pela aplicação do artigo 27 do CDC. Com isso, a empresa ré argumentou que o contrato tinha sido firmado entre partes igualitárias, não estando presente nesse caso, nenhum pólo mais fraco na relação contratual. Ou seja, nenhuma das partes era considerada mais vulnerável que a outra, excluindo a aplicação do CDC.

Porém, o ministro Castro Filho esclareceu que toda discussão girava apenas em torno de caber ou não nesse caso, o Código de Defesa do Consumidor ao transporte marítimo. E, em seu argumento, apresentado no decorrer do processo, o ministro expôs sua opinião em torno do art. $2^{\circ}$ do CDC, afirmando que o artigo da lei n. 8.078/90 trata de pessoas físicas e jurídicas, que utiliza um serviço como destinatária final, de forma geral. E, que a tese de que se trata de partes igualitárias não apresentava nenhuma sustentação, pois a empresa responsável por transportar e socorrer a mercadoria em casos de avarias e outros acidentes apresentava caráter de pessoa jurídica, assumindo os direitos e a situação de outra empresa, que na relação de consumo estava vinculada a legislação consumerista.

O ministro também esclareceu que não importa o fim a que se destina o material transportado, seja econômico ou não, fazendo com que isso não altera a natureza da relação contratual. Justificando essa afirmação através de decisões de outros casos, como no Resp. 
236.755/SP, Rel. Min. César Asfor Rocha, DJ 15.10.01; ADResp. 224.554/SP, Rel. Min. Nancy Andrighi, DJ 25.02.02; Resp. 224.995/SP, Rel. Min. Ruy Rosado de Aguiar, DJ 15.04.02, e outros.

Por fim, o ministro relata que é tranquila a incidência do CDC nesse caso, assim como, para os transportes aéreos, para a mesma situação ocorrida nesse processo, afirmando que o CDC já é utilizado em casos de transporte aéreo de forma pacificada. Com isso, concluindo que a indenização aplicável seria a do prazo quinzenal previsto no art. 27 da lei n. 8.078/90.

Processo n. 858.358-4 / RJ, relatado pelo Ministro Jorge de Oliveira Vargas, da oitava câmara cível da comarca de Maringá, julgado em 17 de maio de 2012.

O processo trata de uma decisão que acolhe exceção de incompetência em ação de reparação de danos decorrentes de transporte marítimo, por tratar de uma relação de consumo amparada pela teoria maximalista, tendo o importador como destinatário final do serviço firmado, com a possibilidade de se aplicar o Código de Defesa do Consumidor no caso.

O processo n. 858.358-4 foi relatado e discutido na 5a vara cível de Maringá. Tendo como agravante a empresa Gonçalves \& Tortola S/A e como agravado a empresa Compañia Sud Americana de Vapores S/A.

A 8a Câmara Cível da Comarca de Maringá entendeu como possível a utilização do Código de Defesa do Consumidor no caso, assim como, a permanência de ação na Vara Cível da região pelo fato da empresa ter sido considerada consumidora (destinatária) final, por ter realizado um serviço de transporte caracterizado com a chegada da mercadoria ao destino final, caracterizando-se uma relação de consumo entre a transportadora e a empresa que solicitou o serviço.

A empresa foi compreendida como destinatária final e, consequentemente, como consumidora, pois o tribunal adotou a teoria maximalista ao interpretar o artigo 20 do CDC, que versa sobre a definição de consumidor. Conforme previamente apresentado, esta teoria defende que apenas importa a relação de entrega até o destinatário final (destinatário final fático), não importando, se a mercadoria foi enviada com o intuito de continuar na cadeia de produção ou não (não importando a destinação final econômica).

Sobre o processo, ressalta-se que durante a abertura, a empresa solicitou que o caso fosse enviado para o estado de sua sede (Barueri), afirmando que em sua região o caso poderia ser julgado de forma mais competente, porém, a transportadora entrou com recurso para que o processo fosse julgado no local onde ocorreu o fato, por se considerar consumidora e merecer o benefício de ajuizar a demanda em seu próprio domicílio, não importando se a sede da empresa demandada ficaria em Maringá ou em Barueri. Dessa forma, os desembargadores do Tribunal de Justiça do Paraná deram voto favorável à transportadora, justificando-o com base na teoria maximalista.

Por fim, através das análises jurisprudenciais, podemos perceber que a aplicabilidade do Código de Defesa do Consumidor (CDC) irá ser determinada de acordo com o entendimento de cada Tribunal de Justiça presente no território nacional, assim como, de cada ministro presente no processo, se tratar-se de uma corte superior. Tendo cada um de forma individual um entendimento a respeito do assunto. A diferença de entendimento é o fator determinante para 
chegar a uma conclusão final sobre a aplicabilidade do Código de Defesa do Consumidor, nos casos julgados em cada corte.

Apesar disso, percebeu-se que nos últimos 15 anos ocorreram uma maior tendência da aplicação do CDC em casos que envolvem o transporte marítimo de mercadorias, como também, nas cinco análises realizadas nesse trabalho, em que sua maioria foi possível a aplicação do CDC.

\section{CONSIDERAÇÕES FINAIS}

Diante do processo de globalização e dos primórdios do comércio, podemos perceber a evolução constante e acelerada das atividades comerciais, assim como, a influência e a importância do transporte marítimo para as operações comerciais brasileiras e para o comércio exterior como um todo. Comprovada a sua importância pela ideia dos autores Castro Jr (2007) e Damásio (2009), bem como, por dados da Secretaria de Comércio Exterior (SECEX) e pelo Departamento de Operações da Confederação Nacional do Comércio (CNC), que esclarece que o transporte marítimo detêm, em números percentuais, 90\% das exportações brasileiras, sendo o transporte mais utilizado nas atividades de comércio exterior.

A Agência Nacional de Transporte Aquaviário (ANTAQ) realizou uma pesquisa e em 2011 concluiu que se tratando do modal marítimo, foram exportados em números percentuais de mercadorias, em toneladas, cerca de $96 \%$. E, em relação às importações, cerca de $89 \%$ foram por esse modal. Estes dados ratificam as ideias dos autores citados anteriormente.

Com a utilização crescente do transporte marítimo, mais comuns tornaram-se as lides envolvendo este tipo de modal e seus contratos, por isso foi-se necessária a utilização de diplomas legais, como o Código Civil e o Código Comercial, para suprir as deficiências e resolver as problemáticas que pudessem surgir com o uso desse tipo de modal.

Comparado com outros tipos de modal, como o aéreo, que é regido pelo Código Comercial, Código Brasileiro de Aeronáutica e também regido pelo Código de Defesa do Consumidor, para o transporte de uso próprio ou de mercadorias, está pacificado o uso deste último Código. Percebe-se que o transporte marítimo não é regido pelo CDC, com isso, houve a necessidade de estudar o porquê de não ocorrer uma pacificação quando se trata da utilização do Código de Defesa do Consumidor em contratos marítimos de mercadorias, visto que, em contratos de transporte de bagagens e de questões pessoais, como mudanças, este uso estaria pacificado. Diferentemente do transporte marítimo, o transporte aéreo em sua totalidade é regido pacificamente pelo $C D C$.

O Superior Tribunal de Justiça (STJ) vem discutindo a possibilidade de aplicação do CDC em contratos de transporte marítimo, mas ainda trata-se de uma discussão polêmica, pois, encontram-se de um lado os interesses dos exportadores e importadores, e do outro, dos armadores e agentes de carga (NVOOC's). Há ainda opiniões divergentes de juristas que defendem a aplicação do CDC, mas divergem quanto à aplicação da teoria finalista ou da maximalista.

Quando se trata da teoria finalista, os defensores esclarecem que deverá ocorrer uma relação contratual entre fornecedor e consumidor, sendo o consumidor, destinatário final fático e econômico, devendo utilizar o bem para uso próprio. Dessa forma, o consumidor não poderá usar o produto e/ou mercadoria na cadeia produtiva. Se ocorrer esse fato, ele deixará de ser 
consumidor, razão pela qual não poderá ser aplicado o CDC à demanda judicial, pois, a questão não seria oriunda de uma relação de consumo.

Já os defensores da teoria maximalista, esclarecem que quando se trata de relação contratual entre fornecedor e consumidor, o que realmente importa é que a entrega do produto e/ou mercadoria seja realizada de maneira satisfatória para ambos. Ou seja, a relação de consumo acaba no momento que o transporte é finalizado, não importando se o produto e/ou mercadoria continuará ou não fazendo parte da cadeia produtiva, apenas importa que o consumidor seja destinatário final fático. Os defensores dessa teoria são mais flexíveis para a aplicação do CDC em contratos de transporte marítimos de mercadorias.

Sobre a discussão da utilização do CDC em contratos de transporte marítimo de mercadorias, percebeu-se que a ideia perde forças quando estudada a aplicação desse diploma legal em contratos de transporte marítimo de bagagens, pois é destinado ao transporte de bens para consumo próprio, bem como os bens de exercício de atividade profissional. Por outro lado, a necessidade de se criar um regime legal para proteger o consumidor, seja ele destinatário fático ou econômico, deu-se pelo crescente desenvolvimento do comércio e da ampliação da publicidade, gerando o consumo em massa. Essas e diversas opiniões dão mais contornos para o debate do uso do CDC nesses tipos de contratos.

É importante também perceber que, a utilização do CDC cuida das partes desiguais, tendo como prioridade as partes mais fracas envolvidas na realização de um contrato, protegendo-as. As partes contratuais devem estar inseridas nas definições de consumidor e fornecedor de bens (e serviços), respectivamente dos artigos $2^{\circ}$ e $3^{\circ}$ do CDC. Por outro lado, o Código Civil, trata da relação contratual entre iguais, ou seja, partes que merecem tratamentos iguais. Assim como esses, os demais diplomas legais também apresentam suas particularidades.

Por fim, acredita-se que num futuro breve, o CDC, nos casos de contratos de transporte marítimo de mercadorias, será utilizado de forma majoritária, passando a ser considerado a ferramenta mais utilizada disponível para as decisões envolvendo o transporte marítimo de mercadorias, sempre que for possível aplicar a teoria maximalista. Como apresentado, tem-se que ao tratar-se de contratos de transporte marítimo de pessoas e/ou bagagens, o respectivo diploma está pacificado. O cenário do Direito de Transporte e da norma consumerista são dinâmicos, por isso percebe-se uma tendência renovadora caminhando para uma melhor aceitação da aplicação do CDC, na ótica da teoria maximalista. Tem-se como exemplo os contratos de fretamento, nos quais uso do CDC é possível.

Ressalte-se, por fim, a importância desta temática para o curso de comércio exterior em razão das inúmeras e custosas consequências que a aplicação de um ou outro diploma legal a um contrato de transporte internacional pode acarretar e a contribuição dos resultados apresentados nesse trabalho para conhecimento de demais pesquisadores que tenham 0 interesse de realizar novas pesquisas que girem em torno do assunto abordado. Pesquisas futuras são bem vindas e necessárias, posto que a temática ainda está em evolução.

\section{REFERÊNCIAS BIBLIOGRÁFICAS}

1. AGUIAR, Ruy Rosado de Junior. Contrato de transporte de pessoas e o novo código civil. Disponível

em: 
<http://www.stj.jus.br/internet_docs/ministros/Discursos/0001102/Contrato\%20\%20de\%20 \%20Transporte\%20\%20de\%20\%20Pessoas\%20e\%200\%20Novo\%20C\%C3\%B3digo\%20Civil.rtf >. Acesso em: 10 jul. 2014.

2. ALMEIDA, João Batista. Manual de Direito do Consumidor. Editora Saraiva. 3a Edição, revista. 2009.

3. ANTAQ. Agência Nacional de Transportes Aquaviários. Panorama da navegação marítima e de apoio. Disponível em: <http://www.antaq.gov.br/portal/pdf/BoletimPortuario/Panorama NavegacaoMaritimaApoio2011.pdf>. Acesso em: 10 jul. 2014.

4. AMORA, SOARES. Minidicionário Tropical da Língua Portuguesa. São Paulo, Saraiva, 1999, 5a Edição.

5. AMBITO JURÍDICO. A incidência do Código de Defesa do Consumidor nos contratos marítimos de transporte de mercadorias. Disponível em: <http://www.ambitojuridico.com.br/site/index.php?n_link=revista_artigos_leitura\&artigo_id=7104>. Acesso em: 17 out. 2013.

6. APRENDENDO A EXPORTAR. Planejamento Estratégico. Transporte aéreo. Disponível em: <http://www.aprendendoaexportar.gov.br/maquinas/planejando_exp/plan_estrategico/logi stica/trans_a.asp>. Acesso em: 10 jul. 2014.

7. APRENDENDO A EXPORTAR. Planejamento Estratégico. Transporte ferroviário. Disponível em:

<http://www.aprendendoaexportar.gov.br/maquinas/planejando_exp/plan_estrategico/logi stica/trans_f.asp>. Acesso em: 10 jul. 2014.

8. APRENDENDO A EXPORTAR. Planejamento Estratégico. Transporte marítimo. Disponível em:

<http://www.aprendendoaexportar.gov.br/maquinas/planejando_exp/plan_estrategico/logi stica/trans_m.asp>. Acesso em: 10 jul. 2014.

9. APRENDENDO A EXPORTADOR. Planejamento Estratégico. Transporte rodoviário. Disponível em: <http://www.aprendendoaexportar.gov.br/maquinas/planejando_exp/plan_estrategico /logistica/trans_r.asp>. Acesso em: 10 jul. 2014.

10. BERVIAN, Pedro A. CERVO, Amado L. DA SILVA, Roberto. Metodologia Científica. Editora Pearson. Education do Brasil. 2007. $6^{\circ}$ Edição.

11. CÓDIGO CIVIL BRASILEIRO (2002). Lei no 10.406: de 10 de Janeiro de 2002. Disponível em: <http://www.planalto.gov.br/ccivil_03/leis/2002/l10406.htm>. Acesso em: 10 jul. 2014.

12. CÓdIGO COMERCIAL (1850). Lei no 556: de 25 de Junho de 1850. Disponível em: <http://www.planalto.gov.br/ccivil_03/leis/l0556-1850.htm>. Acesso em: 10 jul. 2014.

13. CÓDIGO DE DEFESA DO CONSUMIDOR (1990). Lei $\mathbf{n}^{\circ}$ 8.078: de 11 de Setembro de 1990. Disponível em: <http://www.planalto.gov.br/ccivil_03/leis//8078.htm>. Acesso em: 10 jul. 2014.

14. COMEXBLOG. A aplicação do CDC nos transportes marítimos de bagagens. Disponível em: http://www.comexblog.com.br/direito-em-foco/a-aplicacao-do-cdc-nos-transportesmaritimos-de-bagagens>. Acesso em: 24 mai. 2013.

15. COMEXBLOG. Aplicação do Código de Defesa do Consumidor no transporte marítimo. Disponível em: http://www.comexblog.com.br/destaques/aplicacao-do-codigo-de-defesa- 
do-consumidor-no-transporte-maritimo>. Acesso em: 24 mai. 2013.

16. COMEX ONLINE. A importância dos modais no comércio exterior e a relevante vantagem do transporte marítimo. Disponível em: <http://comexonline.wordpress.com/2013/03/04/aimportancia-dos-modais-no-comercio-exterior-e-a-relevante-vantagem-do-transportemaritimo/>. Acesso em: 10 jul. 2014.

17. CNC. Conselho Nacional de Carregadores. $\mathbf{O}$ transporte marítimo como força motriz para desenvolvimento da economia mundial. Disponível em: <https://www.cncangola.com/index.php/noticias/19-o-transporte-maritimo-como-forca-motriz-paradesenvolvimento-da-economia-mundial>. Acesso em: 10 jul. 2014.

18. CONPEDI. Regras das convenções internacionais em contratos de transporte marítimo. Disponível em: <http://www.conpedi.org.br/manaus/arquivos/anais/fortaleza/3629.pdf>. Acesso em: 23 fev. 2014.

19. CONSULTOR JURÍDICO. CDC não cabe em transporte não operador de navio. Disponível em: <http://www.conjur.com.br/2013-jan-01/cdc-nao-aplica-transporte-maritimo-nao-operadornavio>. Acesso em: 24 mai. 2013.

20. CREMONEZE, Paulo Henrique. O contrato de transporte marítimo de cargas e o código de defesa do consumidor - um futuro escudo contra as regras de Roterdam e instrumento de luta pela justiça. Disponível em: <http://www.mclg.adv.br/2012/artigos_integra.asp? codigo $=30>$. Acesso em: 24 mai. 2013.

21. CREMONEZE, Paulo Henrique. Do Código de Defesa do Consumidor. Disponível em: <http://jus.com.br/artigos/3672/do-codigo-de-defesa-do-consumidor\#ixzz2VIlocBxr>. Acesso em: 4 jun. 2013.

22. DINIZ, Maria Helena. Curso de Direito Civil Brasileiro. 18a . ed. v. 1. São Paulo. Saraiva, 2002.

23. DIREITO E HUMANIDADES. Contratos internacionais de seguro marítimo de mercadorias uma análise comparativa entre a legislação brasileira e a inglesa. Disponível em: <http://seer.uscs.edu.br/index.php/revista_direito/article/viewArticle/885>. Acesso em: 4 jun. 2013.

24. DSPACE. A aplicabilidade do CDC no transporte aéreo e a mitigação dos diplomas especiais. Disponível em: <http://dspace.c3sl.ufpr.br:8080/dspace/handle/1884/31046>. Acesso em: 4 mar. 2014.

25. EGOV. A nova teoria contratual e os contratos de transporte internacionais de carga. Disponível em: <http://www.egov.ufsc.br/portal/sites/default/files/anexos/9394-9393-1PB.pdf>. Acesso em: 2 jan. 2014.

26. EMERJ - ESCOLA DE MAGISTRATURA DO RIO DE JANEIRO. Responsabilidade Civil do Transportador Marítimo. Disponível em: <http://www.emerj.tjrj.jus.br/paginas/trabalhos_conclusao/1semestre2012/trabalhos_1201 2/leonardorodrigues.pdf>. Acesso em: 4 jun. 2013.

27. ENEGEP 2002. Encontro Nacional de Engenharia de Produção. Logística e transportes: uma discussão sobre os modais de transporte e o panorama brasileiro. Disponível em: <http://tecspace.com.br/paginas/aula/mdt/artigo01-MDL.pdf>. Acesso em: 10 jul. 2014.

28. GIL, A. C. Métodos e técnicas de pesquisa social. $5^{\circ}$ Edição. São Paulo: Atlas, 2000.

29. GIBERTONI, Carla Adriana Comitre. Teoria e prática do direito marítimo. 2. ed. atual., rev. e 
ampl. Rio de Janeiro: Renovar, 2005. 581 p. ISBN 85-7147-475-3.

30. GUIALOG. A logística do comércio exterior brasileiro. Disponível em: <http://www.guialog.com.br/Y661.htm>. Acesso em: 10 jul. 2014.

31. IBDS - INSTITUTO BRASILEIRO DE DIREITO DO SEGURO. Do transporte marítimo: elementos importantes ao seguro de carga transportadoras via marítima. Disponível em: <http://www.ibds.com.br/artigos/DoTransporteMaritimo.pdf>. Acesso em: 22 agos. 2013.

32. JUNIOR, Osvaldo Agripino de Castro. O diálogo entre as fontes no direito marítimo: Código Civil e Código de Defesa do Consumidor. Disponível em: <http://www.conpedi.org.br/ manaus/arquivos/anais/campos/osvaldo_agripino_junior.pdf>. Acesso em: 22 agos. 2013.

33. JUS. Do Código de Defesa do Consumidor: Aspectos relevantes ao direito marítimo e ao direito do seguro. Disponível em: <http://jus.com.br/revista/texto/3672/do-codigo-dedefesa-do-consumidor>. Acesso em: 4 jun. 2013.

34. KINCAID. STJ decide pela inaplicabilidade do código de proteção e defesa do consumidor no transporte marítimo. Disponível em: <http://www.kincaid.com.br/b_newsletter.php?id_ noticia=472\&PHPSESSID=328a8cf75054c5bc294316eadec6c729>. Acesso em: 13 mai. 2014.

35. LAKATOS, Eva Maria. MARCONI, Marina de Andrade. Fundamentos da metodologia científica. $7^{\circ}$ Edição, 2010. Editora Atlas.

36. LOGWEB. Importância de aplicação de leis no transporte marítimo. Disponível em: <http://www.logweb.com.br/novo/conteudo/artigo/24479/importancia-de-aplicacao-deleis-no-transporte-maritimo/>. Acesso em: 4 jun. 2013.

37. MIGALHAS. Da incidência do Código de Defesa do Consumidor nos contratos de transporte e fretamento marítimo. Disponível em: <http://www.migalhas.com.br/dePeso/16,MI703 49,101048-Da+incidencia+do+Codigo+de+Defesa+do+Consumidor+nos+contratos+de>.

Acesso em: 13 out. 2013.

38. MIYADA, William. Conceito e Origens do Contrato de Transporte. Webartigos. São Paulo, 28 de março de 2010. Disponível em: <http://www.webartigos.com/artigos/conceito-e-origensdo-contrato-de-transporte/38975/>. Acesso em: 11 mar. 2014.

39. NET SABER ARTIGOS. Modal marítima. Disponível em: <http://artigos.netsaber.com.br/ resumo_artigo_1563/artigo_sobre_modal_maritima>. Acesso em: 10 jul. 2014.

40. OCTAVIANO, Eliane M. Curso de Direito Marítimo. 1. ed. v. 2. Editora Manole Ltda, 2008.

41. OCTAVIANO, Eliane M. Da Incidência do Código de Defesa do Consumidor nos Contratos de Transporte e Fretamento Marítimo. In: XV Congresso Nacional do CONPEDI/UEA - Manaus, ISBN: 978-85-87995-80-3, 2006, Manaus.

42. PORTOGENTE. A incidência do código de defesa do consumidor nos contratos internacionais de transporte de mercadorias. Disponível em: <http://portogente.com.br/ colunistas/eliane-octaviano/a-incidencia-do-codigo-de-defesa-do-consumidor-nos-contratosinternacionais-de-transporte-de-mercadorias-32121>. Acesso em: 4 mar. 2014.

43. PESQUISA EM TRANSPORTES. A importância do direito marítimo e da regulação dos transportes e portos para o desenvolvimento da logística. Disponível em: <http://www.pesquisaemtransportes.net.br/relit/index.php/relit/article/viewArticle/320>. Acesso em: 4 jun. 2013. 
44. RKL ADVOCACIA. O código de defesa do consumidor e o novo código civil. Disponível em: <http://www.rkladvocacia.com/arquivos/artigos/art_srt_arquivo20080731121902.pdf>. Acesso em: 10 jul. 2014.

45. SBDA - ASSOCIAÇÃO BRASILEIRA DEDIREITO AERONÁUTICO E ESPACIAL. Avarias e Claims no direito marítimo e direito aeronáutico. Disponível em: <http://sbda.org.br/revista/ 1822.pdf>. Acesso em 4 mar. 2014.

46. SEGRE, German. Manual prático de comércio exterior. 4ạ Edição. São Paulo, Editora Atlas S/A, 2012.

47. SEVERINO, Antônio Joaquim. Metodologia do trabalho científico. 23a Edição revista e atualizada. São Paulo, Editora Cortez, 2007.

48. SUPREMO TRIBUNAL DE JUSTIÇA. RECURSO ESPECIAL N² 286.441, da terceira turma do Estado do Rio Grande do Sul. 7 de novembro de 2012.

49. SUPREMO TRIBUNAL DE JUSTIÇA. RECURSO ESPECIAL N²36.755, da terceira turma do Estado de São Paulo. 8 de maio de 2012.

50. SUPREMO TRIBUNAL DE JUSTIÇA. AGRAVO EM RECURSO ESPECIAL $\mathbf{N}^{\circ} \mathbf{3 5 5 . 7 1 7}$, da quarta turma do Estado do Rio de Janeiro. 27 de junho de 2014.

51. SUPREMO TRIBUNAL DE JUSTIÇA. RECURSO ESPECIAL N 302.212, da terceira turma do Estado do Rio de Janeiro. 27 de junho de 2005.

52. TRIBUNAL DE JUSTIÇA DO ESTADO DE PARANÁ. RECURSO ESPECIAL N 858.358-4, da oitava câmara cível da comarca de Maringá. 17 de maio de 2012.

53. UNIFEBE. Os contratos de transporte marítimo internacional de carga, as convenções internacionais e os instrumentos para a busca da uniformização do direito marítimo. Disponível em: <http://www.unifebe.edu.br/revistadaunifebe/20122/artigo009.pdf>. Acesso em: 10 jul. 2014.

54. UNIVALI. Limitação da responsabilidade civil relativa ao transporte de passageiros e às suas bagagens por via marítima: Convenção de Atenas 2002. Disponível em: <http://www6.univali.br/seer/index.php/nej/article/view/4682/2594>. Acesso em: 24 jan. 2014. 